\title{
Environmental variability in the monsoon-westerlies transition zone during the last 1200 years: lake sediment analyses from central Mongolia and supra-regional synthesis
}

\author{
Fang Tian $^{\mathrm{a}, \mathrm{b}, \mathrm{c}, *}$, Ulrike Herzschuh ${ }^{\mathrm{a}, \mathrm{b}}$, Anne Dallmeyer ${ }^{\mathrm{d}}$, Qinghai Xu ${ }^{\mathrm{c}, \mathrm{e}}$, Steffen Mischke ${ }^{\mathrm{b}, \mathrm{f}}$, \\ Boris K. Biskaborn ${ }^{\mathrm{a}, \mathrm{b}}$ \\ ${ }^{a}$ Alfred Wegener Institute, Helmholtz Centre for Polar and Marine Research, Research Unit Potsdam, Telegrafenberg A43, Potsdam 14473, Germany \\ ${ }^{\mathrm{b}}$ Institute of Earth and Environment Science, University of Potsdam, Karl-Liebknecht-Str. 24, Potsdam 14476, Germany \\ ${ }^{c}$ College of Resources and Environment, Hebei Normal University, East Road of Southern 2nd Ring, Shijiazhuang 050024, China \\ ${ }^{\mathrm{d}}$ Max Planck Institute for Meteorology, KlimaCampus, Bundesstrasse 53, Hamburg 20146, Germany \\ ${ }^{\mathrm{e}}$ Key Laboratory of Western China's Environmental System (Ministry of Education), Lanzhou University, 222 Southern Tianshui Road, Lanzhou 730000, \\ China \\ ${ }_{\mathrm{f}}^{\mathrm{f}}$ Institute of Geological Sciences, Free University of Berlin, Malteserstasse 74-100, Berlin 12249, Germany
}

\section{A R T I C L E I N F O}

\section{Article history:}

Received 11 December 2012

Received in revised form

29 April 2013

Accepted 9 May 2013

Available online 9 June 2013

\section{Keywords:}

Pollen

Grain size

TOC

Asian monsoon

Westerlies

Late Holocene

Vegetation change

Mongolia

\begin{abstract}
A B S T R A C T
A high resolution multi-proxy (pollen, grain size, total organic carbon) record from a small mountain lake (Lake Khuisiin; 46.6 ${ }^{\circ} \mathrm{N}, 101.8^{\circ} \mathrm{E} ; 2270 \mathrm{~m}$ a.s.l.) in the south-eastern Khangai Mountains of central Mongolia has been used to explore changes in vegetation and climate over the last 1200 years. The pollen data indicates that the vegetation changed from dry steppe dominated by Poaceae and Artemisia (ca AD 760-950), to Larix forest steppe (ca AD 950-1170), Larix-Betula forest steppe (ca AD 1170-1380), meadow dominated by Cyperaceae and Poaceae (ca AD 1380-1830), and Larix-Betula forest steppe (after AD 1830). The cold-wet period between AD 1380 and 1830 may relate to the Little Ice Age. Environmental changes were generally subtle and climate change seems to have been the major driver of variations in vegetation until at least the early part of the 20th century, suggesting that either the level of human activity was generally low, or the relationship between human activity and vegetation did not alter substantially between AD 760 and 1830. A review of centennial-scale moisture records from China and Mongolia revealed that most areas experienced major changes at ca AD 1500 and AD 1900. However, the moisture availability since AD 1500 varied between sites, with no clear regional pattern or relationship to present-day conditions. Both the reconstructions and the moisture levels simulation on a millennium scale performed in the MPI Earth System Model indicate that the monsoon-westerlies transition area shows a greater climate variability than those areas influenced by the westerlies, or by the summer monsoon only.
\end{abstract}

(c) 2013 Elsevier Ltd. All rights reserved.

\section{Introduction}

The past millennium is one of the most important periods for studying environmental changes, as it covers both naturallydriven environmental changes and changes resulting from human influences (Buttler et al., 1996). Investigations covering this period therefore have the potential to differentiate between the influences

\footnotetext{
* Corresponding author. Alfred Wegener Institute for Polar and Marine Research, Research Unit Potsdam, Telegrafenberg A5, Potsdam 14473, Germany. Tel.: +49 331 2882220.

E-mail addresses: Fang.Tian@awi.de, tfhebtu@sohu.com (F. Tian).
}

that climate has had on ecosystems and those due to localized human activities, thus enabling improved predictions of future environmental responses to these various influences. Climate information covering this period has relied on modeling studies (Bauer et al., 2003) and climate reconstructions based, for example, on tree ring analyses (Briffa et al., 1990; D’Arrigo et al., 2000, 2001), and on lake sediment investigations (Chen FH et al., 2010). Previous studies have indicated that ecosystems have been affected by recent climatic warming relative to the background pre-1850 temperatures, particularly in the mountainous regions of Europe (Granados and Toro, 2000; Leonelli et al., 2011), North America (Hughen et al., 2000), and the northern high-latitudes (Mackay et al., 2005; Bjune et al., 2009). In contrast, however, pollen and 
diatom analyses from two lakes on the Tibetan Plateau have indicated only minor environmental changes (Wischnewski et al., 2011a, b), in agreement with studies from low latitude mountains (Ryves et al., 2011; Wang et al., 2011). The question therefore arises whether mountainous ecosystems in Asia are particularly resilient, or particularly sensitive, to climatic changes on centennial to decadal time scales.

The present-day Mongolian climate is influenced by a number of atmospheric circulation systems. In addition to the year-round influence of the westerlies, the winter climate is primarily controlled by the intense Siberian high pressure system and the summer climate by north part of the Asian low pressure system (Gong et al., 2001; Tudhope et al., 2001; Wang et al., 2009). These complex climatic systems render Mongolia a climatically sensitive area, as has been confirmed through climate-proxy studies on various time scales (D'Arrigo et al., 2000; Pederson et al., 2001; Fowell et al., 2003; An et al., 2008). However, the climatic history of Mongolia and the adjacent areas of northern China still have many controversies and uncertainties. For example, many researchers have assumed that the Mongolia and northern China region was arid during the early Holocene (Grunert et al., 2000; Herzschuh et al., 2004; Wang et al., 2004; Feng et al., 2005; Chen et al., 2008; Liu et al., 2008; Yang and Scuderi, 2010; Yang et al., 2011; Zhang et al., 2012), but also a wet early Holocene has been suggested by some records from that region (Prokopenko et al., 2007; Rudaya et al., 2009; Murakami et al., 2010; Xu et al., 2010). Although some studies suggest that temperatures decreased during the Little Ice Age (LIA), reconstructed and modeled moisture levels and hydrological conditions do not show consistent variations across different parts of Mongolia and northern China (Wang et al., 2003; Liu et al., 2004; Mayewski et al., 2004). Global-scale reconstructions indicate that the LIA was followed by a warming trend in the latter part of the 19th century and during the 20th century (IPCC, 2007), but high resolution environmental records from the Asian mid-latitude region are rare and dating problems, together with the marked variability in climate and orography, may be responsible for inconsistencies in climate change interpretations between the various studies. The complex spatial differences in climatic variations during the history of the Asian mid-latitude region on centennial to decadal time scales is thus only poorly understood, which means that the future effects of climate change on Mongolian ecosystems cannot be reliably projected and indicates the urgent need for further research into spatial variations in climate patterns.

Mongolian steppes form one of the largest continuous pasturelands in the world, with approximately one third of today's population relying on herding as a primary source of livelihood (Chuluun and Ojima, 2002; Asner et al., 2004). The grazing history of these Mongolia grasslands is believed to extend back over at least 4000 years (Shinneman et al., 2009), and in particular since about 2000 years ago, starting with the Scythians and then followed by the Huns and the Mongolian Empire (Zaitseva et al., 2004; van Geel et al., 2004; Rösch et al., 2005). Mongolia was probably continuously inhabited, but details on the herding economy and nomadic life-style of its inhabitants before the 20th century are scarce. Between 1918 and 1990, the livestock comprised predominantly monospecific herds of sheep, but since that time the proportion of goats and cattle in the herds has increased. These animals are considered to be more destructive to trees and shrubs than sheep because of their different plant preferences (Vallentine, 2001; Sankey et al., 2006, 2009; Wang et al., 2009). The contemporary Mongolian vegetation is thus assumed to have been modified, at least to some extent, by human activities (Gunin et al., 1999; Rösch et al., 2005), and in mountain steppes grazing can lead to substantial floristic and edaphic changes (Zemmrich et al., 2010).
However, evidence from northern Mongolia suggests that the present-day vegetation pattern has been primarily influenced by climate and relief (Schlütz et al., 2008). It therefore remains unclear to what extent the Mongolian steppe ecosystem is entirely natural.

Despite the clear need for information on environmental changes over centennial to decadal time scales, no records focusing on these time scales have hitherto been published from Mongolia. We therefore present herein new information on environmental variations that have occurred over approximately the last 1200 years, based on multi-proxy analyses of sediment core from a small lake in the Khangai Mountains of central Mongolia. Our investigations focused on the following questions: (1) How has the vegetation changed during the last $\sim 1200$ years? (2) When - if at all - did humans become the main driver of regional-scale vegetation dynamics? (3) How are global climate signals from the last millennium, such as the Medieval Warm Period (MWP), the LIA, and the Current Warm Period (CWP), reflected in Mongolia's environment? (4) How did the climate history of the Asian midlatitude region vary between the areas controlled by the different climate systems?

\section{Regional settings}

The Khangai mountain system is one of the main elements of the Inner Asian mountain belt. It was formed by the Caledonian Orogeny during the late Silurian and early Devonian, and consists mainly of basalt (Yarmolyuk et al., 2007). The present-day climate in the southern part of the Khangai Mountains is a typical temperate continental climate, with cold-dry winters dominated by the Siberian/Mongolian high pressure system, and warm-wet summers influenced by the Asian low pressure system (Wang et al., 2009). Moisture from the Asian summer monsoon rarely reaches the area (Gunin et al., 1999; Sato et al., 2007) and hence the westerlies are the dominant moisture supply for this montane area (Chen FH et al., 2010). The region receives most of its precipitation during the summer (Angerer et al., 2008). Precipitation increases zonally with increasing latitude, and varies azonally with altitude in the mountainous areas in Mongolia (Sato et al., 2007). The precipitation gradient in Mongolia is reflected in the north-south vegetation transition through five zones (Fig. 1a): (1) taiga, consisting mainly of Larix sibirica, sometimes mixed with Pinus sibirica, Abies, Cedrus and Picea; (2) mountain/forest steppe, characterized by Larix sibirica-Betula forest in combination with a Poaceaedominated herb layer; (3) steppe/dry steppe, in which Poaceae grow together with Caragana and Artemisia; (4) desert steppe, which is mainly a mixture of Poaceae, Artemisia and Chenopodiaceae; (5) desert, dominated by low shrubs and semi-shrubs, most of which belong to the Chenopodiaceae, Asteraceae, Polygonaceae, Zygophyllaceae, Tamaricaeae, Fabaceae, Rosaceae and Convolvulaceae (Hilbig, 1995; Gunin et al., 1999). In the Khangai Mountains, plant communities change with increasing altitude from dry steppe to wetter mountain steppe, forest steppe, and alpine meadow (Hilbig, 1995).

The soils beneath the forests of the Khangai Mountains have been described as permafrost-affected taiga soils (Sharkhuu, 2003; Krasnoshchekov, 2010). The lower limit of continuous permafrost on south-facing slopes ranges from altitudes of $2200-3200 \mathrm{~m}$, and its average thickness ranges between 100 and $250 \mathrm{~m}$. The lower limit of sporadic permafrost is at altitudes of between 600 and $700 \mathrm{~m}$ (Sharkhuu, 2003), and the active layer has a thickness of about $1.5 \mathrm{~m}$ (Krasnoshchekov, 2010).

Lake Khuisiin is located in the south-eastern part of the Khangai Mountains (Fig. 1a), in an area characterized by deeply-etched relief that has been exaggerated by the action of glaciers. The lake basin is separated from the nearby valley by a dam of lateral moraine that 

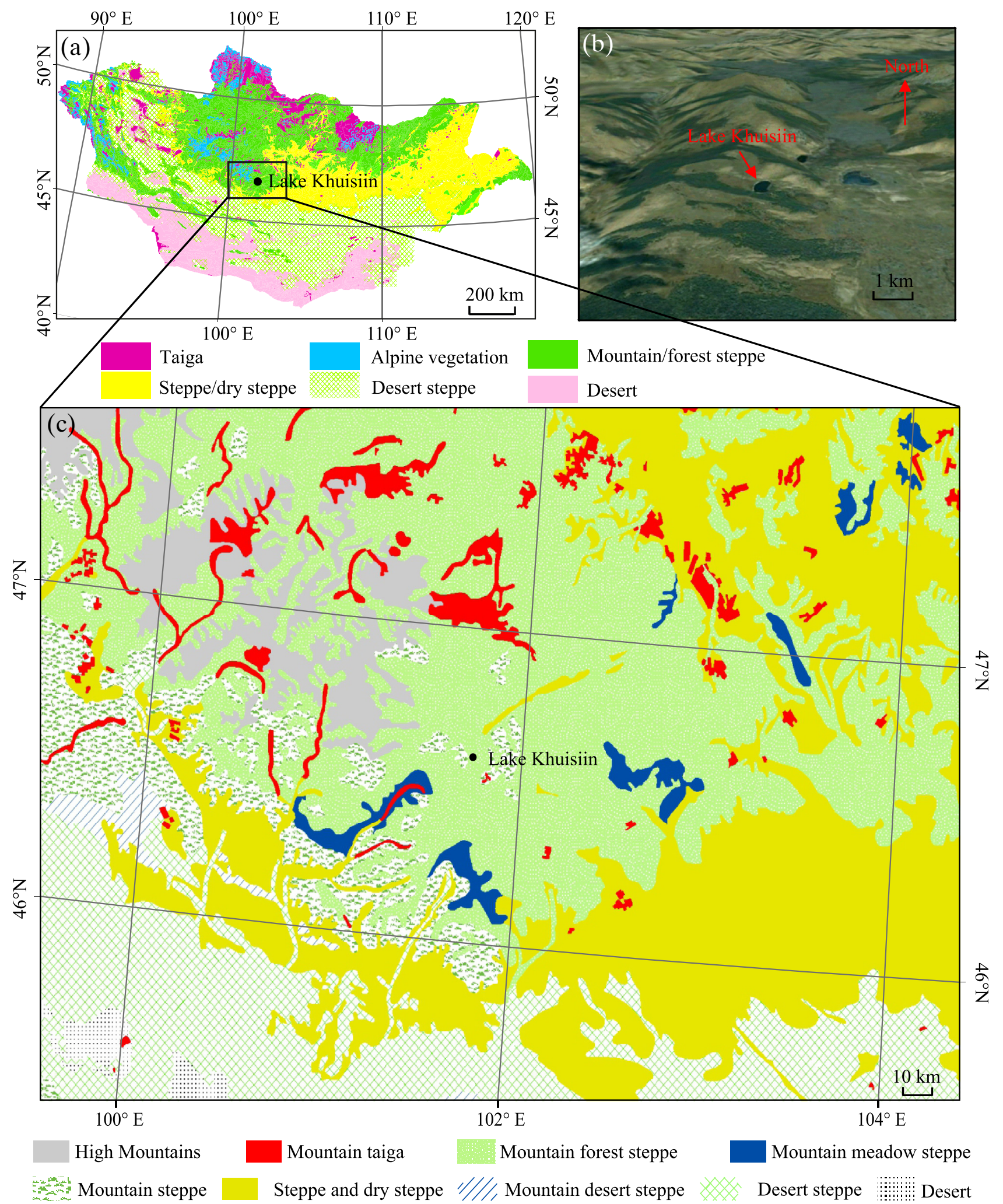

Fig. 1. Location of Lake Khuisiin and vegetation types in the surrounding areas.

was probably formed during the last glacial period (Fig. 1b, Gunin et al., 1999; Lehmkuhl et al., 2004). The lake is surrounded by forest steppe, characterized by patches of Larix sibirica or Larix sibirica-Betula forest on northern slopes, and steppe vegetation (festuce-herb, fescue-sedge-herb) on southern slopes (Fig. 1b, c,
Gunin and Vostokova, 1995; Saandar and Sugita, 2004; Krasnoshchekov, 2010). This asymmetric vegetation distribution can be explained by the fact that exposed southern slopes receive greater insolation and thus retain less moisture than north-facing slopes (Esper, 2000). The Khangai Mountains have been one of the 
most important herding districts in Mongolia, predominantly for sheep and goats.

\section{Materials and methods}

\subsection{Coring, dating methods, and age modeling}

A $26.4 \mathrm{~cm}$ long sediment core (Mo-13B, $\left.46.6^{\circ} \mathrm{N}, 101.8^{\circ} \mathrm{E}\right)$ was collected in 2005 from the center of Lake Khuisiin, at a water depth of $7.4 \mathrm{~m}$ (Fig. 1b). The core was cut in the field into slices $0.4 \mathrm{~cm}$ thick ( 4 slices were $0.6 \mathrm{~cm}$ thick), resulting in 68 samples for laboratory analysis.

In order to achieve a reliable chronology we used two different dating techniques on untreated original material from the core samples. The first technique involved ${ }^{210} \mathrm{~Pb} /{ }^{137} \mathrm{Cs}$ dating performed at the Liverpool University Environmental Radioactivity Laboratory (UK), and the second involved radiocarbon $\left({ }^{14} \mathrm{C}\right)$ dating of five samples at the Poznan Radiocarbon Laboratory (Poland) and a single sample at the Leibniz Laboratory for Radiometric Dating and Isotope Research (Christian Albrechts University of Kiel, Germany). We established the age-depth model based on the method proposed by Blaauw and Christen (2011) using "Bacon" package (selecting the IntCal09 radiocarbon calibration curve for calibrating) in R 2.15.0 (R Development Core Team, 2012).

\subsection{Pollen analyses methods and data treatment}

A total of 68 samples were taken for pollen analysis giving a mean resolution of $\sim 18 \mathrm{yr}$ per sample, with $1.5 \mathrm{ml}$ of original sediment being processed for each sample. Pollen preparation followed the modified acetolysis procedure (Faegri and Iversen, 1989), which included $\mathrm{HCl}, \mathrm{KOH}, \mathrm{HF}$, and acetolysis treatment and sieving to remove fine particles. A known quantity of Lycopodium spores (approximately 27,637 grains) was initially added to each sample for calibration of pollen concentrations (Maher, 1981).

Pollen grains were counted under an Olympus optical microscope at $400 \times$ magnification, with pollen grain identification based on the relevant literature (Moore et al., 1991; Wang et al., 1997; Beug, 2004). More than 500 terrestrial pollen grains were counted for each sample. Pollen percentages were calculated based on the total number of pollen grains from terrestrial pollen taxa and used to construct a pollen diagram, as well as for numerical analysis. The definition of pollen zone boundaries was based on the results of a Constrained Incremental Sum of Squares cluster analysis (CONISS) performed with TILIA software (Grimm, 1987, 1991).

In order to detect patterns of vegetation change and identify relationships between different taxa, ordination techniques were performed using CANOCO software, version 4.5 (ter Braak, 1988; ter Braak and Smilauer, 2002). Principal component analysis (PCA) was chosen for ordination, and square-root transformation was applied to the data. Eighteen pollen taxa with percentages $>0.5 \%$ in at least three samples were used for the PCA and, in addition, Artemisia to Cyperaceae $(\mathrm{A} / \mathrm{Cy})$ ratios, the grain size end-members, TOC values, atomic TOC/N and atomic TOC/S ratios, were all included as supplementary variables in the biplots.

\subsection{Grain size analysis and end-member modeling}

Approximately $2 \mathrm{~g}$ of sediment was used from each of 39 samples for grain size analysis. Prior to analysis, $10 \mathrm{ml}$ of $\mathrm{H}_{2} \mathrm{O}_{2}$ (35\%) was added to samples on alternate days until all reactions ceased, in order to remove organic carbon, after which $100 \mathrm{ml}$ of acetic acid $\left(\mathrm{CH}_{3} \mathrm{COOH}, 10 \%\right)$ was added to remove calcium carbonate. Finally, the soluble salt sodium pyrophosphate $\left(\mathrm{Na}_{4} \mathrm{P}_{2} \mathrm{O}_{7} \cdot 10 \mathrm{H}_{2} \mathrm{O}\right)$ was added to ensure that clay-sized particles would not aggregate. Grain size analysis of the bulk sediment was carried out for each sample from the upper $5.6 \mathrm{~cm}$ of core, the only exceptions being three samples for which there was insufficient material available (from depths of 0 $0.4 \mathrm{~cm}, 0.8-1.1 \mathrm{~cm}$, and $3-3.4 \mathrm{~cm}$ ). From 5.6 to $26.4 \mathrm{~cm}$ alternate samples were analyzed. A Laser Coulter LS200 particle size analyzer was used at the AWI in Potsdam (where measurements were performed between 2 and 8 times for each sample, in order to obtain an average value), resulting in 39 samples and 76 size classes from 0.375 to $409.6 \mu \mathrm{m}$. We report the results as volume percentages for clay $(0-2 \mu \mathrm{m}$ particle diameters), silt $(2-62.5 \mu \mathrm{m}$ particle diameters), and sand (62.5-500 $\mu \mathrm{m}$ particle diameters).

The End-Member Modeling Algorithm (EMMA) developed by Weltje (1997) was applied in order to obtain robust end-members (EMs) from the total set of grain size measurements, and to determine the proportional contributions of these EMs to all sediments in the lake on the basis of the measured grain size distributions (Weltje and Prins, 2003, 2007). The cumulative explained variance in grain size was used to determine the minimum number of potential EMs that can explain at least $95 \%$ of the total variance in the original data. The maximum value of the mean coefficient of determination $\left(r^{2}\right)$ for the number of EMs was used to determine the maximum number of EMs. We tested the robustness of the EMs and then extracted the final robust $\mathrm{EM}(\mathrm{s})$ and residual member. The variances in $r^{2}$ with grain size and age give the explained proportion of variance for each variable and each time slice, respectively (Dietze et al., 2012). Scores of robust and residual members for the other 29 samples that were not analyzed were interpolated using the AnalySeries program software (Paillard et al., 1996). The interpolated data was only applied in the PCA plot in this study.

\subsection{Elemental analysis}

Freeze-dried material from 39 samples (the same samples that were used for grain size analysis) was triturated for further elemental analysis. Total carbon (C), total nitrogen $(\mathrm{N})$, total sulfur (S), and total organic carbon (TOC) contents were measured with a vario MAX C analyzer. The samples for TOC measurement were first treated with $\mathrm{HCl}(10 \%)$ at a temperature of $80{ }^{\circ} \mathrm{C}$ to remove carbonate. The atomic TOC/N and atomic TOC/S ratios were calculated using the percentages of TOC, total N, and total S, and the molar masses of C, N and S (Meyers and Lallier-Vergès, 1999). TOC was used as a variable for describing the abundance of organic matter in the sediments, and the atomic TOC/N ratio was calculated to examine the relative importance of autochthonous and allochthonous sources of organic material.

\subsection{Re-analysis of moisture records}

Moisture records from 27 sites in China and Mongolia, providing evidence of environmental change on centennial time scales (lake sediments, ice cores, stalagmites, etc., but no tree-rings), have been coded for each site using a five-point moisture scale. The highest value (2) indicates the wettest conditions and the lowest value $(-2)$ indicates the driest conditions, while $(0)$ indicates moisture conditions similar to today. A figure for relative wetness was assigned to each 20-year time interval, covering approximately the last 1200 years. The index of moisture variations for each record and for each time slice was calculated as the proportion of the number of times the moisture codes differed from those of the present day within that particular record or time slice.

To interpret the spatial pattern of moisture variations we compared the reconstructions with climate modeling results. For this purpose, we analyzed the full forcing experiment 'mil0010' (Jungclaus, 2008) performed within the framework of the Millennium project, coordinated by the Max Planck Institute for Meteorology 
(Jungclaus et al., 2010). This simulation had been undertaken with the comprehensive Earth System Model ECHAM5/JSBACH-MPIOMHAMOCC by including time-dependent orbital, solar, volcanic, and greenhouse-gas forcing as well as anthropogenic land use change.

In this study, we concentrated on the simulated spatial pattern of effective moisture (precipitation minus evaporation) variations from AD 850 to 1950. The simulated time-series of effective moisture were filtered using a $100 \mathrm{yr}$ moving average.

\section{Results}

\subsection{Dating}

Freeze-dried material from the uppermost 15 samples (0$5.6 \mathrm{~cm}$ depth) was analyzed for ${ }^{210} \mathrm{~Pb},{ }^{226} \mathrm{Ra}$ and ${ }^{137} \mathrm{Cs}$. The ${ }^{210} \mathrm{~Pb}$ date of 1963 was placed at a depth of about $1.1 \mathrm{~cm}$, in good agreement with the $0.9-1.3 \mathrm{~cm}$ depth suggested by the ${ }^{137} \mathrm{Cs}$ record. Detailed illustrations of fallout radionuclides are provided in the Supplementary Material (Fig. S1), and the results of radiometric dating are summarized in the Supplementary Material (Fig. S2). Total ${ }^{210} \mathrm{~Pb}$ activity reached equilibrium with that of the supporting ${ }^{226} \mathrm{Ra}$ at a depth of around $2.6 \mathrm{~cm}$ (Supplementary Material, Fig. S1a). Unsupported ${ }^{210} \mathrm{~Pb}$ concentrations, calculated by subtracting ${ }^{226} \mathrm{Ra}$ activities from the total ${ }^{210} \mathrm{~Pb}$ concentrations, initially increase with depth, reaching a maximum value in the $0.8-1.1 \mathrm{~cm}$ section. Below this they decrease very rapidly and more or less exponentially with depth (Supplementary Material, Fig. S1b). The record of ${ }^{137} \mathrm{Cs}$ activity versus depth in this core (Supplementary Material, Fig. S1c) has a well-resolved peak in the $0.9-1.3 \mathrm{~cm}$ section that probably records the 1963 fallout maximum from the atmospheric testing of nuclear weapons.

Six AMS ${ }^{14} \mathrm{C}$ samples have been dated along the Mo-13B core (Table 1). The age-depth model was established on the basis of these six ages and the $\mathrm{Pb}$ age of $\mathrm{AD} 1950$ at a depth of approximately $1.3 \mathrm{~cm}$ using the "Bacon" package in R (Fig. 2). In our data analysis we applied the dates inferred from ${ }^{210} \mathrm{~Pb}$ for the upper $2.4 \mathrm{~cm}$ of the core (Supplementary Material, Figs. S1, S2), the interpolated dates between 2.4 and $8 \mathrm{~cm}$ (based on the sedimentation rate calculated using the $\mathrm{Pb}$ date of $\mathrm{AD} 1841 \mathrm{at} 2.4 \mathrm{~cm}$ and the ${ }^{14} \mathrm{C}$ date of $\mathrm{AD} 1391$ at $\left.8 \mathrm{~cm}\right)$, and the dates inferred from the "Bacon" model for the depths between 8 and $26.4 \mathrm{~cm}$ (Fig. 2; Table 1).

\subsection{Pollen data and results from multivariate analyses}

Fifty two pollen taxa were identified in the sediment core. Artemisia (range: 29-57\%), Poaceae (range: 13-41\%), Cyperaceae (range: $1-15 \%$ ) and Chenopodiaceae (range: $4-12 \%$ ) were the most common taxa throughout the core. The arboreal pollen content ranged between 2.5 and $10.3 \%$ of the total pollen (median: $5.6 \%$ ), mainly comprising Larix, Betula, Pinus, Alnus, Quercus and Salix. The $\mathrm{A} / \mathrm{Cy}$ ratios varied from 2.9 to 35.7 . The percentage diagram

Table 1

Detailed information on radiocarbon dating.

\begin{tabular}{lccr}
\hline Lab. No. & Sample no. & Center depth $(\mathrm{cm})$ & Age ${ }^{14}$ C years \\
\hline Poz-49536 & Mo-13B-22 & 8 & $555 \pm 30$ BP \\
Poz-49537 & Mo-13B-38 & 14.2 & $645 \pm 30$ BP \\
Poz-49539 & Mo-13B-46 & 17.7 & $850 \pm 35$ BP \\
Poz-49540 & Mo-13B-62 & 23.6 & $1080 \pm 30 \mathrm{BP}$ \\
Poz-49541 & Mo-13B-64 & 24.7 & $1075 \pm 30 \mathrm{BP}$ \\
Kia-44751 & Mo-13B-66 & 25.5 & $1168 \pm 17$ BP \\
\hline
\end{tabular}

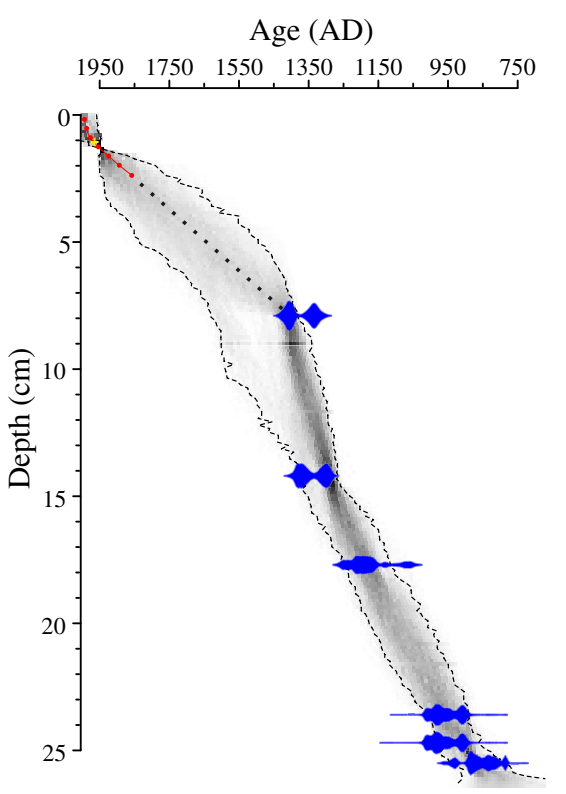

Fig. 2. Bacon age-depth model for the Mo-13B core (core length: $26.4 \mathrm{~cm}$ ), overlaying the calibrated distributions of the individual dates (blue). Dashed lines indicate the model's $95 \%$ probability intervals. The round dots reflect the ${ }^{210} \mathrm{~Pb}$ dating data, indicating a sedimentation rate of $0.1-0.6 \mathrm{~mm} \mathrm{yr}^{-1}$ in the upper $2.4 \mathrm{~cm}$ of the core. The cross is the Cs age at the depth of $1.1 \mathrm{~cm}$; the dotted line indicates the interpolation ages between depths of $2.4-8 \mathrm{~cm}$, using linear model. (For interpretation of the references to colour in this figure legend, the reader is referred to the web version of this article.)

spanning the approximate period between AD 760 and 2005 was divided into five pollen zones, as suggested by depth constrained cluster analyses (Fig. 3).

PCA ordination of 18 terrestrial pollen taxa and sixty eight samples reflects the main features of the pollen diagram and the pattern of vegetation development. The first component, capturing $20.7 \%$ of the pollen data variance (Supplementary Material, Fig. S3), divides the dataset into dry steppe taxa such as Artemisia and Chenopodiaceae, or meadow taxa such as Poaceae, Cyperaceae, Caryophyllaceae and Thalictrum. The second component accounts for $13.7 \%$ of the total variance of species data and distinguishes coniferous arboreal types such as Pinus and Larix, from broadleaved arboreal taxa such as Betula and Alnus. It is noticeable that the $\mathrm{A} / \mathrm{Cy}$ ratio is gathered together with samples from Zone 5 (Supplementary Material, Fig. S3).

\subsection{Grain size data and results from end-member modeling}

The grain size spectra were dominated by silt fractions (62.1$81.9 \%$ ), with the clay (13.4-25.8\%) and sand (0-24.0\%) fractions only accounting for a smaller part of the total. The inversion algorithm for end-member modeling of compositional data suggested the minimum number of EMs considering all weight transformations to be 3 (Fig. $4 \mathrm{a}$ ), and the maximum number to be 7 (Fig. 4b). We therefore used the models with different weight transformations (with percentile ranges of $\mathrm{P}_{1}-\mathrm{P}_{99}, \mathrm{P}_{2}-\mathrm{P}_{98}, \mathrm{P}_{3}-$ $\mathrm{P}_{97}, \mathrm{P}_{4}-\mathrm{P}_{96}$ ) and EMs ranging from 3 to 7 to extract final robust EMs and the residual end-member. One robust member and residual member (describing the remaining noise) were finally identified and are presented in the loadings plot (Fig. 4c). The robust member represents $64.5 \%$ of the total variance within the original data and corresponds to the finer fraction $(1-7 \mu \mathrm{m})$, while the residual member corresponds to a mixture of the coarser fractions (7-300 $\mu \mathrm{m}$, Fig. 4c). The explained proportion 


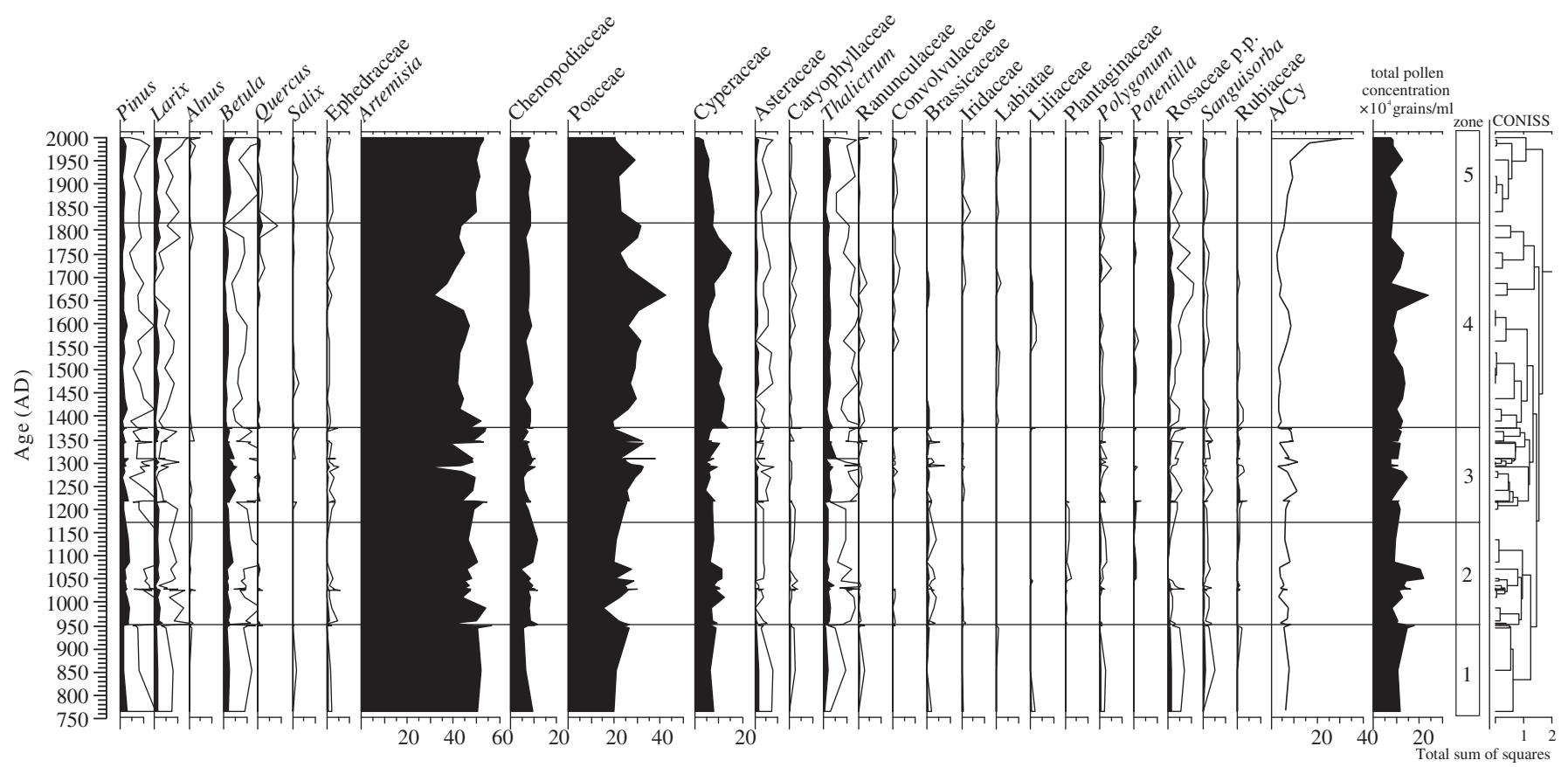

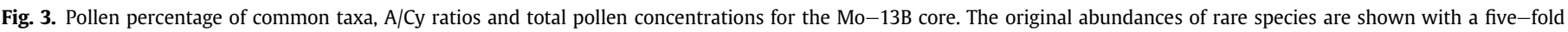
exaggeration (unfilled silhouettes).

of the finer grain size classes $\left(1.5-73 \mu \mathrm{m}\right.$, median $\left.r^{2}: 0.84\right)$ is far higher than that of the other size classes (median $r^{2}: 0.18$ ); the explained proportion of the lower core $(26.4-9.8 \mathrm{~cm}$, AD 7601380 , median $r^{2}: 0.79$ ) is far higher than that of the upper core (median $r^{2}$ : 0.1, Fig. 4c, d, e). The variances in scores for the robust and residual members clearly divide the core into two parts, with the period before ca AD 1380 being dominated by the robust member and the period since AD 1380 by the residual member (Fig. 5).

\subsection{TOC, atomic TOC/N and atomic TOC/S results}

TOC contents in the lower section of the core $(26.4-4.5 \mathrm{~cm}$, ca AD 760-1670) are slightly higher (median: 15.5\%) than in the upper section (4.5-0 cm, after ca AD 1670, median: 13.7\%, Fig. 5). The atomic $\mathrm{TOC} / \mathrm{N}$ ratio was relatively constant throughout, varying between 9.3 and 10.7 (median: 9.9), whilst the atomic TOC/S ratio (median: 61) decreased steadily upwards from 77 at the bottom of the core to 47 at the top. In the PCA plot (Supplementary Material, Fig. S3), the TOC and atomic TOC/S (added as supplementary variables) is related to coniferous pollen taxa, while the atomic TOC/N ratio correlated with meadow taxa.

\subsection{Temporal and spatial analysis of moisture changes}

The moisture codes on the combined pollen and non-pollen data sets for China and Mongolia (Table 2) over the last 1200 years are shown in Fig. 6, indicating that around $70 \%$ of the total records had higher moisture levels between AD 1650 and 1800 than during other periods. The index of moisture variation is relatively stable until AD 1200, followed by rapid increases at ca AD 1500 and AD 1900 (Fig. 6b). Records from the monsoon boundary area have higher moisture variation indexes than those from within the areas of either the westerlies or the monsoon (Fig. 6a). The simulated difference in effective moisture (precipitation minus evaporation) of each grid-box from that of the present-day is shown in Fig. 7a. As in the reconstructions, the climate model reveals greater variability in the effective moisture in the monsoon boundary area than in the core area of the Asian monsoon or in the area dominated by the westerly wind circulation (Fig. 7a). The detrended time series averaged over the western monsoon-westerly transition area (yellow) and averaged over the eastern monsoon-westerly transition area (green) are shown in Fig. 7b, d, indicating four persistent wet phases on the western monsoon margin and seven wet phases on the eastern monsoon margin (indicated by more than one standard deviation difference from average) over the last millennium, with only partial coincidence. The model suggests relatively wet conditions in the entire monsoon-westerly transition area around AD 1200-1300 and around AD 1700-1800, followed by a marked decrease in effective moisture with relatively dry conditions at around AD 1400 and from around AD 1900 to the presentday (Fig. 7a, b, d).

\section{Discussion}

\subsection{Assessment of proxy values}

\subsubsection{Indicator value of pollen taxa and ordination axes for vegetation and climate change}

Lake Khuisiin (radius $\sim 80 \mathrm{~m}$ ) should have a relative small pollen source radius, with the majority of grains originating within 600-800 $\mathrm{m}$ from the lake (Sugita, 1993). The pollen spectrum from the Mo-13B core should therefore reflect vegetation changes in the immediate vicinity of the lake. The conifer Larix sibirica is today the most common and widely distributed tree in Mongolia, with a distribution that extends much further south and east than any other conifer (Gunin et al., 1999). Although Larix sibirica has a greater tolerance of drought than Pinus (Dulamsuren et al., 2009a), increased precipitation and uniform summer temperatures have been shown to result in its improved growth (Gunin et al., 1999; Dulamsuren et al., 2009b, 2010a,b; 2011). Larix is generally considered to be an under-represented taxon owing to its low pollen productivity ( 0.7 relative to Picea, and 0.16 relative to Pinus in the Swiss Alps; Sjögren et al., 2008) combined with poor pollen 

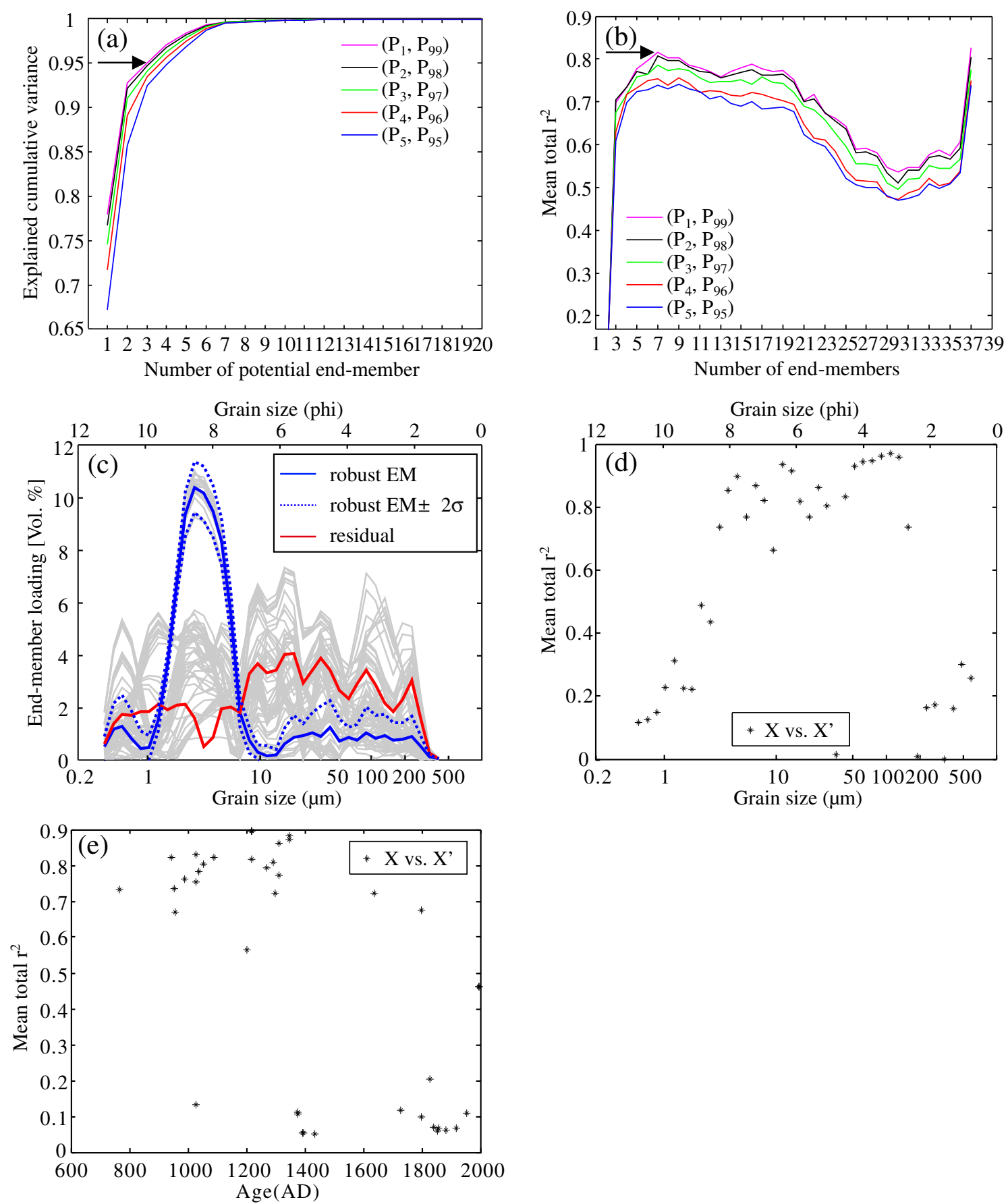

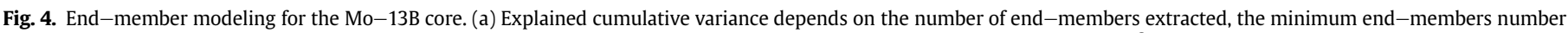

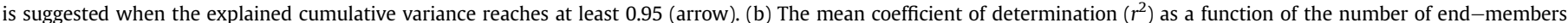

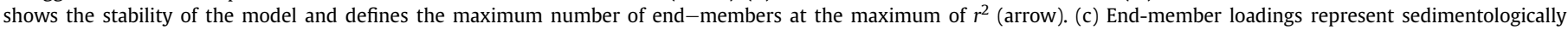

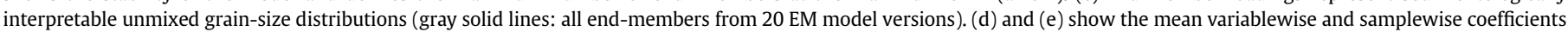
of determination $\left(r^{2}\right)$ between original data $(\mathrm{X})$ and modeled data $\left(\mathrm{X}^{\prime}\right)$ as quantitative error estimates.

preservation and dispersal (Gunin et al., 1999; Tarasov et al., 2000; Ma et al., 2008). Although it forms the most important component of the present-day vegetation around the lake, Larix pollen comprised only $3 \%$ of the total in the uppermost part of our core (Fig. 3). The low but consistent presence of Larix in the pollen spectrum therefore indicates the presence of Larix trees in the Lake Khuisiin surroundings over the last millennium, although the areas that they covered may have varied during that time.
Betula is a common sub-dominant element in the Larix forests of mountainous areas in Mongolia (Hilbig, 1995). It is usually regarded as being over-represented in Asian pollen assemblages because of its high pollen productivity and good pollen preservation (Xu et al., 2007; Ma et al., 2008). Nevertheless, increased Betula pollen percentages during two periods, AD 1170-1380 and AD 1830-2005, indicate variations in the abundance of Betula within the vicinity of the lake. 


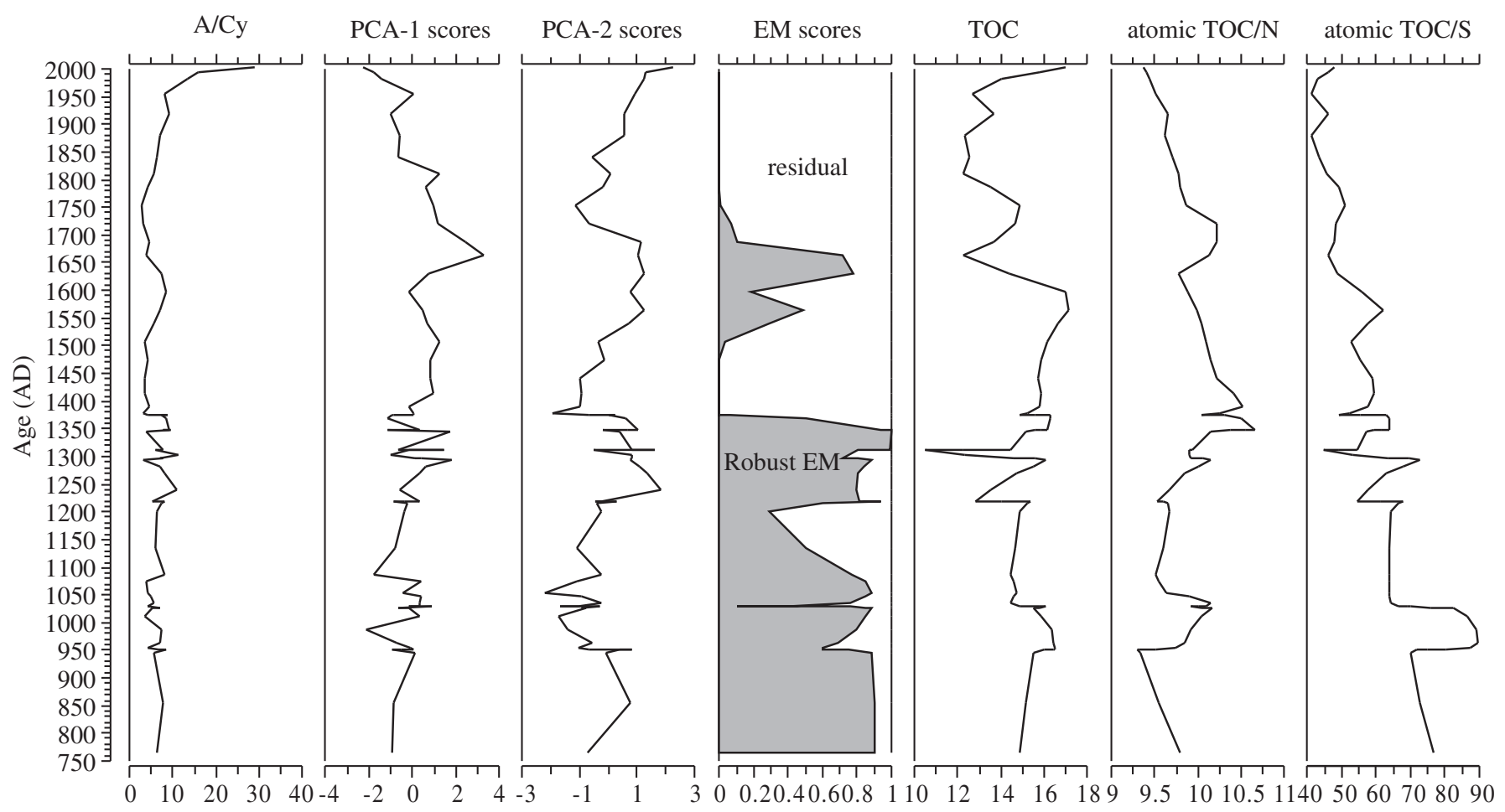

Fig. 5. A/Cy ratios, PCA scores for the first two axes, end-members from grain size distributions, TOC, atomic TOC/N ratio, and atomic TOC/S ratio.

Pinus pollen is well dispersed and greatly over-represented in pollen rain in China and Mongolia (Li, 1993; Li and Yao, 1993; Cao et al., 2007; Ma et al., 2008), and Pinus may not be present in the vicinity of sites where Pinus pollen forms less than $30 \%$ of the total pollen assemblage (Li and Yao, 1990; Xu et al., 2007). The Pinus percentages in our study varied between $0.7 \%$ and $4.2 \%$ over the last 1200 years, suggesting that the Pinus pollen grains were probably transported from the northern or north-western mountainous taiga, a distance of about $350 \mathrm{~km}$. This deduction is supported by the absence of Pinus in the present-day vegetation surrounding the lake.

Poaceae plants are today more abundant than Artemisia and Chenopodiaceae in relatively moist meadow steppe and forest steppe communities, while Cyperaceae plants are common species in the vegetation of cold-wet tundra, forest steppes, and wetlands, in contemporary Mongolia (Gunin and Vostokova, 1995; Hilbig, 1995; Gunin et al., 1999). Both Poaceae and Cyperaceae are under-represented taxa as a result of their low pollen productivities (Sugita et al., 1999; Räsänen et al., 2007; Ma et al., 2008). The presence of more than $10 \%$ Poaceae pollen indicates that this family is dominant in a vegetation community (Li et al., 2005). In this study, Poaceae varied between 13.4 and $41.1 \%$ (median: 23.4\%), indicating that Poaceae plants were the dominant herbaceous component around the lake over the last 1200 years. The Cyperaceae percentages increased (from around 6\%) significantly during two periods (median: 10\% AD 950-1170 and median: 9\% AD 13801830 ), indicating that they may therefore have been the dominant herbaceous species during these two periods.

Artemisia and Chenopodiaceae are important components of today's dry steppe vegetation in Mongolia (Gunin and Vostokova, 1995; Hilbig, 1995; Gunin et al., 1999). Both pollen taxa are commonly over-represented in pollen assemblages due to their high productivities and good transportability (Liu et al., 1999; Li et al., 2011; Poska et al., 2011; Wang and Herzschuh, 2011). Only at those sites where their pollen percentages are $>50 \%$ (for Artemisia) or $>30 \%$ (for Chenopodiaceae), they can be regarded as dominant species in the local vegetation (Xu et al., 2007; Ma et al., 2008). In our core, Artemisia pollen percentages exceeded 50\% during the two periods from AD 760-950 and AD 1830-2005, while Chenopodiaceae pollen percentages varied between 4.4 and 11.8\% (median: $8.16 \%$ ) throughout the whole period investigated, indicating that Artemisia was important during the two periods with high pollen counts, but that Chenopodiaceae never achieved high levels of abundance in the vegetation surrounding the lake during the last millennium.

In contrast to Artemisia, which prefers warm-dry conditions, Cyperaceae is a common element of cold-wet alpine tundra and subalpine forest steppe (Gunin and Vostokova, 1995; Hilbig, 1995; Gunin et al., 1999). In our core, Artemisia and Cyperaceae are the two most important taxa and show greater variation than the other taxa present. A previous study from Lake Telmen, which is $400 \mathrm{~km}$ north-west of Lake Kuisiin (Fowell et al., 2003), revealed high Cyperaceae counts during the middle to late Holocene indicating a cold-wet climate signal. Increasing Artemisia to Cyperaceae ratios $(\mathrm{A} / \mathrm{Cy})$ may therefore be closely associated with an increase in temperature and a decrease in effective moisture, so that this ratio (originally introduced by Herzschuh, 2007; for the Kobresia-rich Tibetan Plateau) can be used as an indicator of temperature and moisture levels in the mountain areas of central Mongolia. High A/ Cy ratios are therefore taken to indicate high temperatures with low moisture levels, and low ratios to indicate low temperatures with high moisture levels.

The first PCA component (PCA-1) distinguishes dry steppe taxa such as Artemisia and Chenopodiaceae from meadow taxa such as Poaceae, Cyperaceae, Caryophyllaceae and Thalictrum. The second PCA component (PCA-2) distinguishes coniferous arboreal types such as Pinus and Larix, from broad-leaved arboreal taxa such as Betula and Alnus. We therefore consider that the PCA-1 scores have a positive correlation with variations in effective moisture, while the PCA-2 scores have a positive correlation with temperature (Fig. 5, Supplementary Material, Fig. S3). The A/Cy ratio appears in the area of the PCA plot with negative PCA-1 scores and positive 
Table 2

Palaeoclimatic records arranged according to the controlling climate system (westerlies or Asian monsoon).

\begin{tabular}{|c|c|c|c|c|c|c|c|}
\hline No. & Sites & $\mathrm{N}\left({ }^{\circ}\right)$ & $\mathrm{E}\left({ }^{\circ}\right)$ & Elev. (m a.s.l) & Archive & Proxies & Reference \\
\hline 1 & Lake Telmen & 48.8 & 97.3 & 1789 & Lake & Pollen & Fowell et al., 2003 \\
\hline 2 & Lake Khuisiin & 46.6 & 101.8 & 2270 & Lake & Pollen & This paper \\
\hline 3 & Lake Balikun & 43.7 & 92.8 & 1583 & Lake & Pollen & Zhong, 1997 \\
\hline 4 & Lake Bosten & 42.1 & 87.1 & 1048 & Lake & Pollen & Chen et al., 2006 \\
\hline 5 & Tarim River & 39.8 & 88.4 & 1434 & River & $\delta^{13} \mathrm{C}$ & Liu et al., 2011 \\
\hline 6 & Badain Jaran desert & 40.1 & 101.5 & 1260 & Core & Pore water analysis & Ma et al., 2003 \\
\hline 7 & Lake Sugan & 38.9 & 93.9 & 2793 & Lake & Chironomid & Chen et al., 2009 \\
\hline 8 & Dunde ice core & 38.0 & 96.4 & 5325 & Ice core & $\delta^{18} \mathrm{O}$ & Thompson et al., 2003 \\
\hline 9 & Lake Hurleg & 37.3 & 96.9 & 2817 & Lake & Pollen & Zhao et al., 2010 \\
\hline 10 & Lake Toson & 37.1 & 97.0 & 1808 & Lake & Pollen & Zhao et al., 2010 \\
\hline 11 & Lake Qinghai & 36.9 & 100.2 & 3198 & Lake & $\delta^{18} \mathrm{O}$ & Zhang et al., 2003 \\
\hline 12 & Guliya ice core & 35.3 & 81.5 & 6200 & Ice core & $\delta^{18} \mathrm{O}$ & Yang et al., 2009 \\
\hline 13 & Lake Kusai & 35.8 & 92.9 & 4470 & Lake & TOC content & Wang et al., 2008 \\
\hline 14 & Lake Goulucuo & 34.6 & 92.5 & 4666 & Lake & Carbonate content & Li et al., 2004 \\
\hline 15 & Lake Chen Co & 28.9 & 90.5 & 4420 & Lake & Elements, grain size & Wang and Zhu, 2008 \\
\hline 16 & Huanglong Cave & 32.7 & 103.8 & 3588 & Stalagmite & $\delta^{18} \mathrm{O}$ & Yang, 2007 \\
\hline 17 & Huangye Cave & 33.6 & 105.1 & 1650 & Stalagmite & $\delta^{18} \mathrm{O}$ & Tan et al., 2010 \\
\hline 18 & Wanxiang Cave & 33.3 & 105.0 & 1200 & Stalagmite & $\delta^{18} \mathrm{O}$ & Zhang et al., 2008 \\
\hline 19 & Lake Daihai & 40.6 & 112.7 & 1225 & Lake & Carbonate content & Jin et al., 2001 \\
\hline 20 & Lake Gonghai & 38.9 & 112.2 & 1860 & Lake & Magnetism & Liu et al., 2011 \\
\hline 21 & Shihua Cave & 39.8 & 115.9 & 200 & Stalagmite & $\delta^{18} \mathrm{O}$ & Ku and Li, 1998 \\
\hline 22 & Buddha Cave & 33.7 & 109.1 & 500 & Stalagmite & $\delta^{13} \mathrm{C}$ & Paulsen et al., 2003 \\
\hline 23 & Lake Dajiu & 31.5 & 110.0 & 1796 & Lake & Pollen & He et al., 2003 \\
\hline 24 & Heshang Cave & 30.5 & 110.4 & 294 & Stalagmite & $\delta^{18} \mathrm{O}$ & Hu et al., 2008 \\
\hline 25 & Dongge Cave & 25.3 & 108.1 & 680 & Stalagmite & $\delta^{18} \mathrm{O}$ & Wang et al., 2005 \\
\hline 26 & Lake Xiaolongwan & 42.3 & 126.4 & 655 & Lake & Clastic content & Chu et al., 2009 \\
\hline 27 & North China & & & & History record & Drought/flood index & Man, 2009 \\
\hline
\end{tabular}

PCA-2 scores, providing further indication that this ratio can be taken as a useful index for investigating variations in both temperature and moisture levels within the study area.

\subsubsection{Value of grain size distributions as indicators of vegetation cover}

Previous studies of lacustrine sediment records from large lakes with inflowing rivers have shown that an abundance of coarser grains reflects a shorter distance between the sampling location and a river mouth, often as a result of lower lake levels, while an abundance of finer grains suggests higher lake levels (Dearing, 1997; Digerfeldt et al., 2000; Wang et al., 2001; Chen et al., 2004). However, in small lakes such as Lake Khuisiin, which has no inflows and is characterized by a low sedimentation rate $\left(0.2 \mathrm{~mm} \mathrm{yr}^{-1}\right)$, aeolian input is likely to make up most of the nonorganic sediment portion. Previous studies in semi-arid areas of China also reached the conclusion that aeolian input makes up most of the lake sediment in lakes that have similar grain size distributions to Lake Khuisiin, due to the strong north-westerly prevailing winds and small amount of surface runoff (Jiang et al., 2004; Zhai et al., 2006; Chen and Zhao, 2009; Yin et al., 2011). We therefore propose that changes in the grain size distribution in sediments from Lake Khuisiin reflect the changes in the vegetation cover in the area surrounding the lake, rather than variations in the lake's water level. The fine particles are more easily transported by wind from afar, while coarser particles are only likely to be moved by strong winds, through erosion from the lake's surroundings and saltation following degradation of the vegetation. In our core, finer particles dominated in the period from AD 760-1380, while coarser particles have been dominant since AD 1380 (Fig. 6). From AD 1380-1830 the increase in the coarser, poorly sorted fraction may have been a result of forest shrinkage due to the lower temperatures, while the further increase in the coarse fraction since AD 1830 may be related to additional vegetation degradation caused by increased human activity in the catchment area, in combination with a drier climate.

\subsubsection{Value of TOC, atomic TOC/N and atomic TOC/S as indicators of environmental change}

TOC is a summary proxy for autochthonous productivity and for allochthonous organic input and preservation, but may also be affected by changes in the inorganic component (dilution effect) (Talbot and Livingstone, 1989; Beuning et al., 1997; Wang et al., 2001). Terrestrial plants usually have atomic TOC/N values greater than 20, whereas plankton have values lower than 10 (Meyers and Ishiwatari, 1993; Meyers, 1994; Hassan et al., 1997). Variations in atomic $\mathrm{TOC} / \mathrm{N}$ ratios can therefore be used to assess the relative proportions of terrestrial and aquatic plant input (Finney and Johnson, 1991; Conroy et al., 2008; Mahapatra et al., 2011).

The atomic TOC/N ratios from our core are almost all below 10 , indicating that any variations in TOC are likely to relate to variations in either productivity or dilution or preservation. The lowest TOC values occurred during the late LIA (LIA: AD 1380-1830, Fig. 6), probably indicating decreased algal productivity due to the cold climate. This period is also characterized by lower Larix and Betula cover and extensive ruderal vegetation (high Rosaceae p.p. values, Fig. 3), with an associated increase in erosion that may have further contributed to the reduction in TOC due to increased mineral input.

\subsection{Environmental changes in the Khangai Mountains during the last $\sim 1200$ years in comparison with other records from China and Mongolia}

In the sections below the environmental changes that have taken place in China and Mongolia over the last $\sim 1200$ years are discussed for five distinct periods of time that were determined on the basis of the pollen assemblages from our core:

(1) AD 760-950: During this period the area around Lake Khuisiin was covered by dry steppe vegetation, with Poaceae and Artemisia as the dominant taxa and patches of Larix. Both the pollen data (i.e. high Artemisia percentages, high A/Cy ratios, high PCA -2 scores, and low PCA-1 scores) and the grain size 


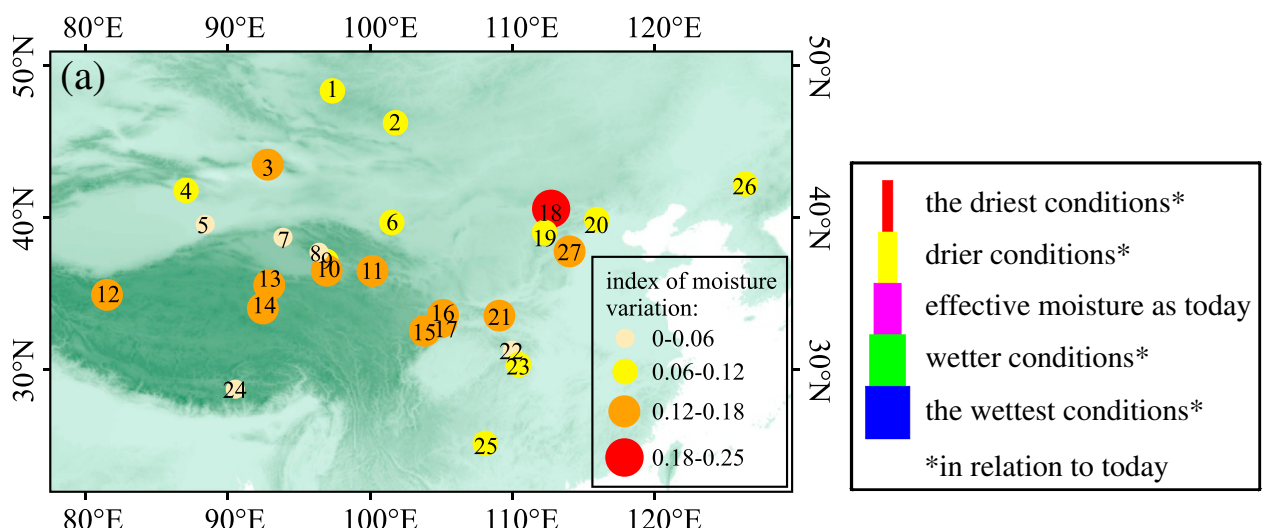

(b)
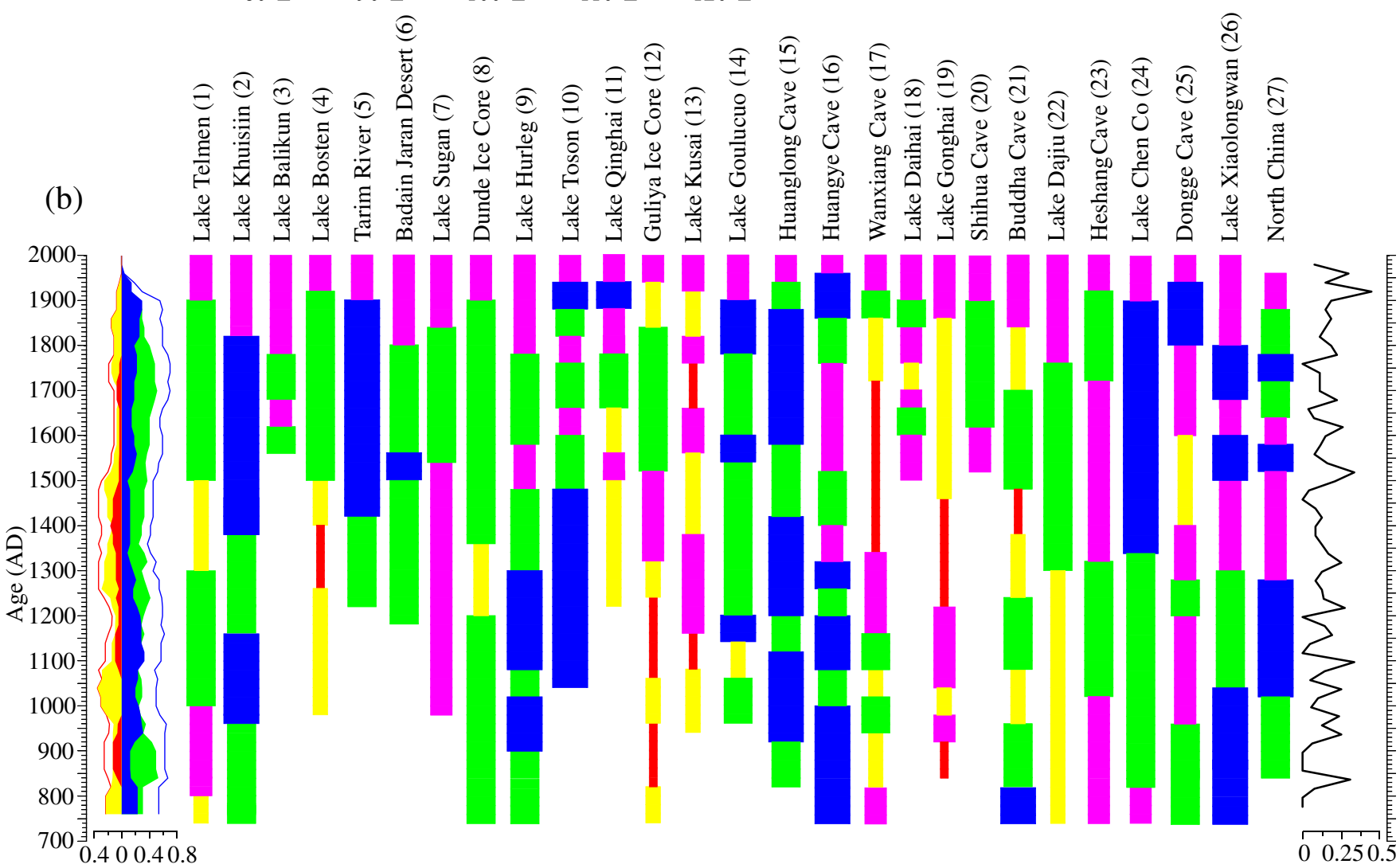

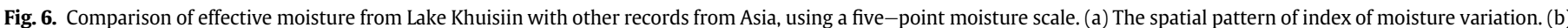

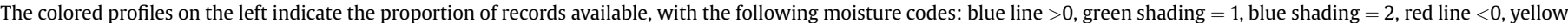
shading $=-1$, and red shading $=-2$; the black profile on the right indicates the index of moisture variations through time.

data (high contributions from the finer fractions) reflect a warm-dry climate in this area. This correlates with the dry conditions recorded in pollen spectra from Lake East Juyanhai in western Inner Mongolia (Chen HF et al., 2010), the Guliya ice core from the western Kunlun Mountains (Yang et al., 2009), Lake Gonghai in north China (Liu et al., 2011), and from Lake Dajiu (He et al., 2003), Wanxiang Cave (Zhang et al., 2008), and Heshang Cave (Hu et al., 2008) in central China (Fig. 6). It also correlates with the large-scale droughts that occurred after $\mathrm{AD}$ 840 in ancient China (the late Tang Dynasty, and the Five Dynasties and Ten Kingdoms period), as documented in historical records (Wang XM et al., 2010). However, during this period, most records (including our core) from China and Mongolia recorded wetter conditions than today (Fig. 6).
(2) AD 950-1170: Cyperaceae became more abundant during this period and Larix patches expanded (Betula was only a minor component in these forest patches), suggesting improved growing conditions for forest steppe. Our results are consistent with a more moist steppe vegetation than that of the preceding dry steppe, as it is also reflected by an increase in the ratio between Artemisia and Chenopodiaceae from Lake Hurleg in the Qaidam Basin, on the north-eastern Tibetan Plateau (Zhao et al., 2010). A relatively cool and moist climate during this period, indicated by relatively low $\mathrm{A} / \mathrm{Cy}$ ratios and $\mathrm{PCA}-2$ scores, is in agreement with historical documents indicating that the Mongolian Plateau experienced a significant reversal of desertification from ca AD 920 until AD 1050 (Wang XM et al., 2010). This period corresponds temporally with the 


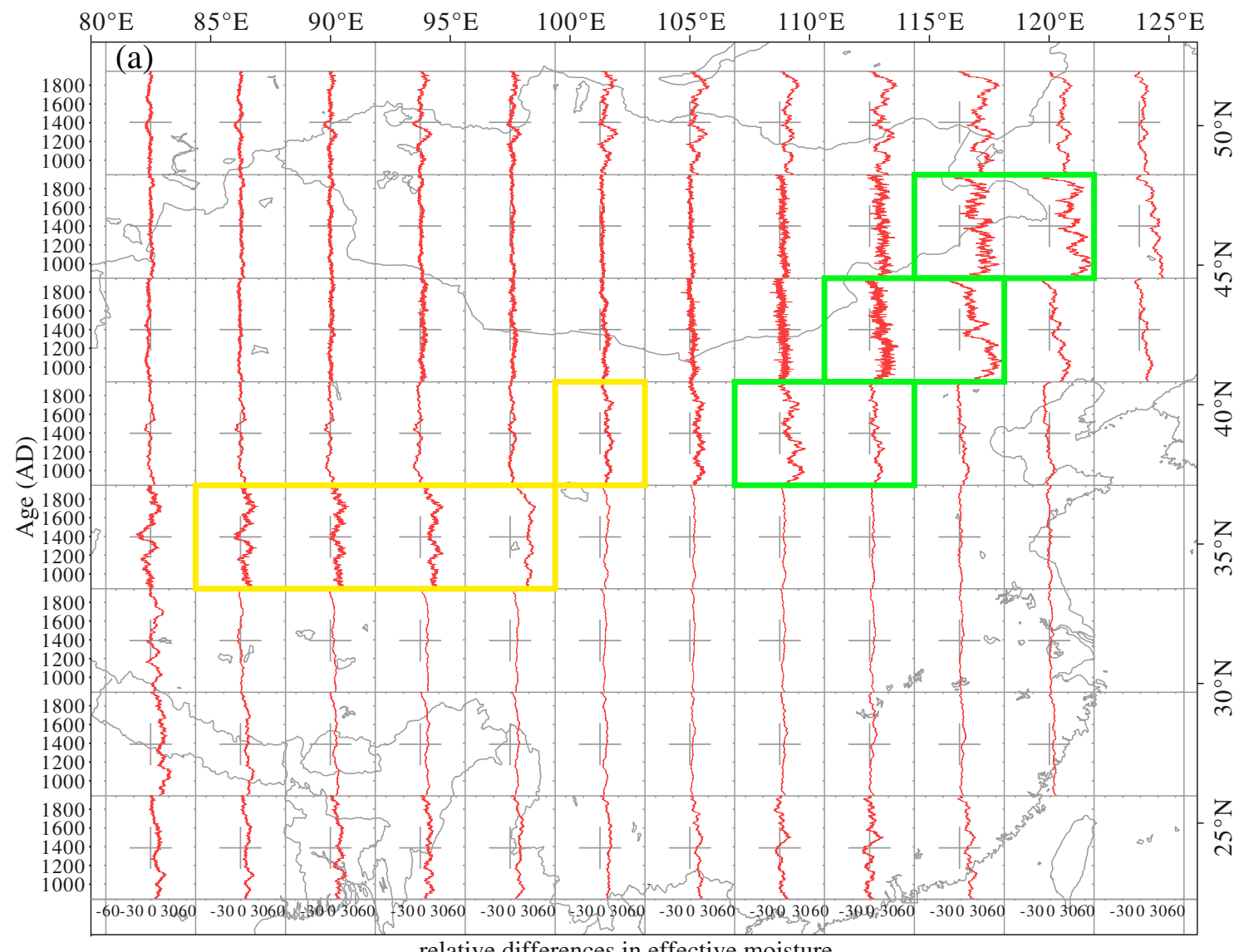

relative differences in effective moisture
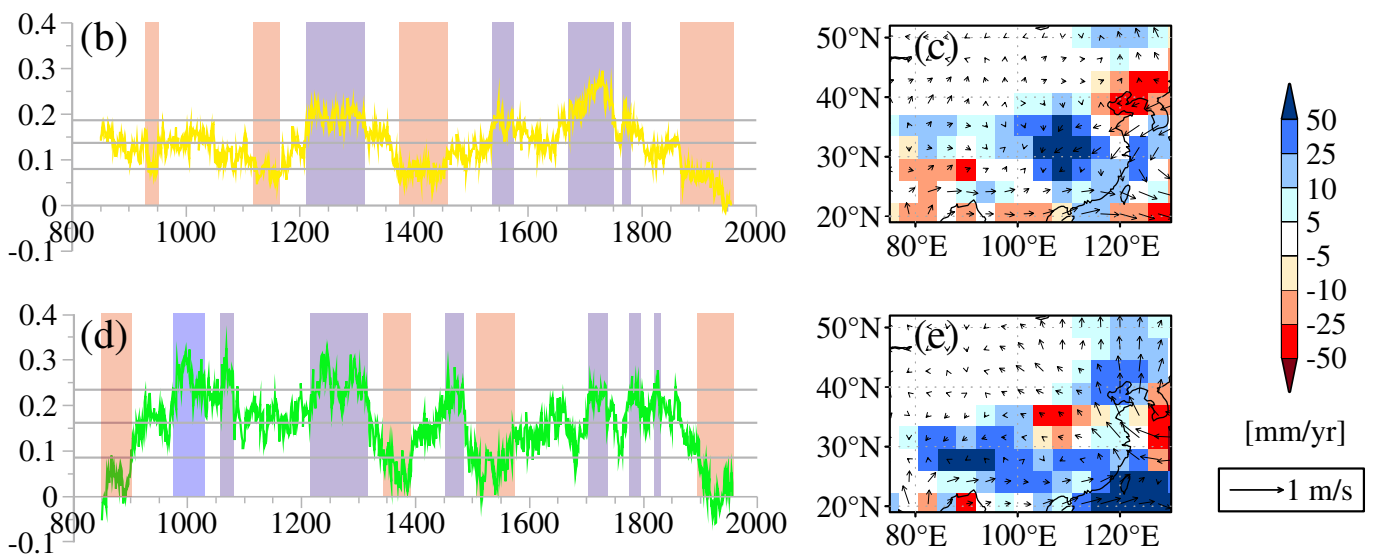

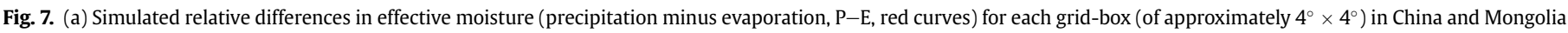

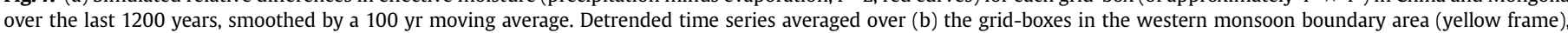

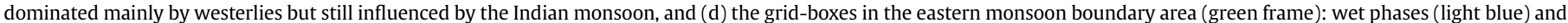

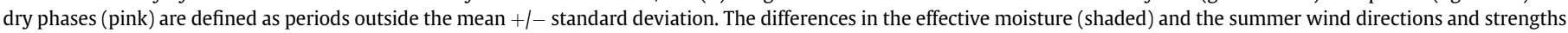

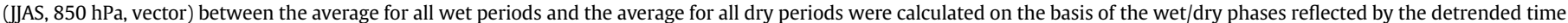

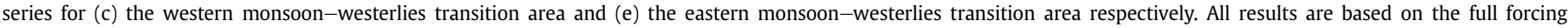
simulation 'mil0010' performed in the comprehensive Earth System Model ECHAM5/JSBACH-MPIOM-HAMOCC (Jungclaus, 2008).

Medieval Warm Period (MWP) in China (AD 900-1300: Wang et al., 2002; Gao et al., 2006), but no clear timing and also no clear pattern of warmer and more moist conditions (e.g., a moist MWP) have been recorded from Lake Telmen in northcentral Mongolia (AD 1000-1300: Fowell et al., 2003), from Lake Kusai (AD 1160-1380: Wang et al., 2008) or Lake Chen Co (AD 820-1350: Wang and Zhu, 2008) on the Tibetan Plateau, from Lake Gonghai in northern China (AD 910-1220: Liu et al.,
2011), or from northern Taiwan (AD 950-1450: Wang et al., 2011). However, variable moisture levels were recorded at the Buddha Cave in central China during the MWP (AD 9651475: Paulsen et al., 2003), and a dry MWP was recorded from Lake East Juyanhai (AD 800-1100: Chen HF et al., 2010), Lake Dajiu (AD 550-1300: He et al., 2003), and the Dunde ice core (ca AD 1200-1370: Thompson et al., 2003, Fig. 6). Our own results, however, did not indicate warming during this period, 
which is consistent with the records from north-western Mongolia (D'Arrigo et al., 2001), southern Xinjiang (Zhong et al., 2004), and Lake Ximencuo on the Tibetan Plateau (Yang, 1996). Thus variations clearly existed during this period between different parts of central Asia, in both the occurrence and the extent of moist conditions. The period from AD 960 to 1100 had a relatively high proportion of dry records compared to other time slices, but most records show similar moisture condition between AD 950 and 1170 to those that existed from AD 760 to 950 , both of which were wetter than present-day conditions (Fig. 6).

(3) AD 1170-1380: Forest steppe covered the area during this period, with Poaceae continuing as the major herbaceous component but with a decreased contribution from Cyperaceae, and with an increase in Betula compared to the previous period. During this time the vegetation in western China was dominated by desert plants, as recorded in the pollen spectra from Lake Bosten (Chen et al., 2006). The pollen spectra, A/Cy ratios, and $\mathrm{PCA}-2$ scores in this study suggest a return to warm-dry conditions between AD 1170 and 1380, which is in agreement with the dry period from AD 1250 to 1370 documented for the Mongolian Plateau (Wang XM et al., 2010). During this period, most lake records from western China (Chen et al., 2006, 2009), the northern Tibetan Plateau (Zhang et al., 2003) and north-central China (Liu et al., 2011), as well as an ice core from the western Tibetan Plateau (Yang et al., 2009), record a decrease in moisture levels, as also do most caves in western and central China (Paulsen et al., 2003; Thompson et al., 2003; Zhang et al., 2008, Fig. 6). However, in the Qaidam Basin dry phases alternated with wet phases (Zhao et al., 2010), and historical sources recorded moist conditions on the north-eastern margin of the Tibetan Plateau (Tan et al., 2011).

(4) AD 1380-1830: A marked increase in both Cyperaceae and Poaceae pollen percentages occurred between AD 1380 and 1830 , suggesting that the vegetation transformed from forest steppe into alpine meadow. For Larix sibirica and Betula trees at, or very close to, the timber-line (above $\sim 2200$ m elevation), temperature rather than drought stress appears to have been the limiting factor for growth (D'Arrigo et al., 2000; Sjögren et al., 2008). The forest reduction during this period was most likely associated with lower temperatures, while the expansion of meadow and the reduction of steppe are likely to have occurred as a result of increased effective moisture. This indicates a reduction in the vegetation cover, which is also supported by a sharp increase in the coarse grained fraction of the core, possibly reflecting vegetation degradation due to the lowering of temperatures. Our results are consistent with the vegetation transformations interpreted for the Lake Bosten area in western China, i.e. the reduction in desert and expansion of desert steppe (Chen et al., 2006).

The highest Cyperaceae and Poaceae pollen percentages, the lowest $\mathrm{A} / \mathrm{Cy}$ ratios, and the lowest arboreal pollen percentages in the entire record imply that this core section represents the coldest period in the last millennium. Lower temperatures would generally lead to reduced evaporation and thus enhance the effective moisture. Moist conditions may also be related to regional topographic features such as the mountains of the Mongolian Plateau (Herzschuh, 2006; Zhao et al., 2009; Zhang et al., 2010). Most records from China and Mongolia show increasing moisture levels and wetter conditions than at present during this phase (Fig. 6). The relatively moist Little Ice Age (LIA) corresponds well temporally with many records from China and Mongolia, but with regional differences in the timing and moisture levels. Most records from northern Mongolia (Lake Telmen: Fowell et al., 2003), western
China (Lake Balikun: Yuan and Han, 1991; Keriya River: Yang et al., 2002; Lake Bosten: Chen FH et al., 2006, 2010; Lake Sugan: Chen et al., 2009; the Tarim Basin: Yang et al., 2006; Liu et al., 2010), and some records from the Tibetan Plateau (Lake Qinghai: Zhang et al., 2003; the Guliya ice core: Yang et al., 2009), indicate a moist LIA between ca AD 1500 and 1900. While records from the Dunde ice core (Thompson et al., 2003), Shihua Cave (Ku and Li, 1998), and Lake Chen Co (Wang and Zhu, 2008) record a moist LIA between ca AD 1600 and 1910, Lake Dajiu (He et al., 2003) and Lake Goulucuo (Li et al., 2004) indicate an earlier onset for the LIA than the other records, starting from AD 1300 and AD 1140, respectively. Records from Buddha Cave indicate a wet-to-dry trend during the LIA, from AD 1475 to 1845 (Paulsen et al., 2003). However, a dry LIA has been reported from sites in Asian monsoonal areas such as at Wanxiang Cave (ca AD 1340-1870: Zhang et al., 2008), Huangye Cave (AD 1530-1860: Tan et al., 2010), Heshang Cave (AD 1250-1750: Hu et al., 2008), and Lake Gonghai (AD 1220-1850: Liu et al., 2011), as well as in monsoon-westerlies boundary areas such as Lake East Juyanhai (AD 1100-1550: Chen HF et al., 2010), on the Tibetan Plateau such as at Lake Kusai (ca AD 1380-1900: Wang et al., 2008), and in eastern China, as recorded in historical documents (Zhang, 2004). Despite apparent inconsistencies during this period between the climatic interpretations from the different records, most of these records indicate a wetter climate than today, and wetter than the first three periods (Figs. 6 and 7).

(5) AD 1830-2005: The period since 1830 has been marked by forest regeneration, by steppe recovery that includes a major component of Artemisia, and by a marked reduction in alpine meadow components. The lower pollen concentrations and TOC values, together with high contributions of coarse minerogenic fractions, indicate low vegetation cover and strong surface soil erosion. Our results are consistent with the vegetation transformation from moist desert steppe to desert reported from Lake Bosten (Chen et al., 2006). In the Qaidam Basin, the decreasing Artemisia to Chenopodiaceae $(\mathrm{A} / \mathrm{C})$ ratio suggests a transformation from "steppe-like" to "desert-like" vegetation over the last three centuries, which is also indicated by a trend toward reduced vegetation cover (Zhao et al., 2010).

Animal husbandry in Mongolia has intensified over the last ca 100 years (Sankey et al., 2006; Na, 2008), and archaeobotanical research has suggested that land-use has made a considerable contribution to the present spatial pattern of vegetation types in areas surrounding the former and current Mongolian capitals of Karakorum and Ulaanbaatar (Rösch et al., 2005). Some researchers have concluded that grazing may have resulted in an increased proportion of Artemisia in the vegetation and a decrease in vegetation cover, resulting in increased soil erosion (Hilbig, 1995; Chen et al., 2006). The increase in Artemisia pollen and the coarsening of grain size since AD 1950 noted in our study may be a reflection of a grazing-related vegetation degradation. Pastoral pressure mainly leads to a reduction in Poaceae grasses such as Festuca lenensis, Poa attenuate, and Koeleria altaica (Gunin et al., 1999), and thus the sharp decrease in Poaceae over the last ca 50 years was possibly associated with over-grazing, in combination with the effects of a drying climate. Historical documents record that major human activities in this area started in the 13th century, when the Mongolian Empire was founded by Chingis Khan (Rösch et al., 2005). However, Schlütz et al. (2008) did not find evidence of human impact in the present-day vegetation patterns of northern Mongolia on the basis of pollen and charcoal records, and pollen data from northern Kyrgyzstan suggest that intensive human activity in this area only started 200 years ago (Beer and Tinner, 
2008). This may indicate either that pollen records from this region are not sensitive enough to reflect the more subtle human impacts, or that human impact in early history might not have been strong enough to cause changes in the vegetation and pollen assemblages (Tarasov et al., 2005). However, we assume that the significant increase in the $\mathrm{A} / \mathrm{Cy}$ ratio, the decrease in Poaceae, and the coarsening of grain size in our core since about the 1950s, which have no analogues in the preceding 1200 years are, at least to some extent, associated with increased human activity, although these features may have also been enhanced by contemporaneous warming. We therefore assume that our record was mainly driven by climate changes, at least until AD 1950.

Although we are unable to accurately differentiate between the influence of climate and man on the vegetation, we assume that the second half of the 20th century was the warmest and driest period of the entire record, which is in agreement with observations and reconstructions from central Mongolia (Natsagdorj, 2000; Batima et al., 2005). Furthermore, reconstructions of snow accumulation on the basis of diatom data from Lake Baikal have shown that the warming trend started in ca AD 1750 (Mackay et al., 2005) and tree ring data have also indicated a persistent warming trend over the last 100 years in Mongolia (Jacoby et al., 1996; D'Arrigo et al., 2000, 2001; Pederson et al., 2001), and over recent decades in northeastern China (Zhang et al., 2011) and on the Tibetan Plateau (Liu et al., 2009). Historical documents have also recorded a warming trend over the last 100 years in western China (Chen et al., 2011). The drying trend since AD 1830 corresponds with most of the records from China and Mongolia (Fig. 6), with the record from Lake Beloye in western Siberia (Krivonogov et al., 2012), and with climate observations from northern China (Ma and Fu, 2006). It can therefore be reasonably concluded that the trend toward drier climatic conditions in China and Mongolia occurred as a response to global warming, as has also been previously suggested by other researchers (Chen et al., 2009; Wang YB et al., 2010). Most proxy studies, as well as the modeling results, indicate that the last hundred years has had the lowest moisture levels of the last millennium in China and Mongolia (Figs. 6 and 7).

\subsection{Moisture variability in China and Mongolia over the last 1200 years}

The density of the reviewed records is too low to allow a detailed identification of spatial moisture patterns, and these records are mostly only semi-quantitative. General patterns of moisture change can however be identified, despite their spatial complexity. The index of moisture variations for China and Mongolia clearly changes at around AD 1500, and again (even more markedly) at about AD 1900, which is in good agreement with our own results.

Both our proxy-synthesis and our climate modeling results indicate that the monsoon-westerly transition area has higher moisture variability than the areas dominated by either the westerlies or the Asian summer monsoon. This may be because the transition zone is sensitive to changes in both circulation systems, with variations in both the westerly winds and the monsoonal circulation having an effect on the regional climate. These two circulation systems are very different in character producing substantial changes in dynamics within the transition zone when the dominant atmospheric regime changes.

The East Asian summer monsoon is a continuous south-easterly flow transporting moist air from the Pacific to the East Asian continental areas. It is controlled by the position of the Western Pacific subtropical high and the strength of the pressure gradient between this high and the continental monsoonal trough (Webster et al., 1998). As with all monsoonal systems, the East Asian monsoon is characterized by marked temporal variability that ranges over multi-millennial to intra-seasonal timescales (Ding, 2007). Variations on centennial to decadal time-scales are mainly related to changes in ocean-surface temperatures, which are affected by variations in major climatic modes such as the El Niño Southern Oscillation or the Pacific Decadal Oscillation (Wang et al., 2000).

The westerly wind circulation in the mid-latitudes prevails over the entire year but is most pronounced during winter. It is characterized by a strong, permanent, westerly wind belt in the upper troposphere that includes the subtropical and polar jet streams, standing waves, and short term tropospheric pressure disturbances embedded in the general flow (Peixoto and Oort, 1992). Variations in the westerlies are mainly related to changes in the North Atlantic Oscillation and the Arctic Oscillation (Hurrell et al., 2003).

A shift from monsoonal influence to prevailing westerlies also implies a shift from summer-dominated precipitation to winterdominated precipitation, which may have a marked effect on, for example, evaporation.

However, the climate model results suggest that the timing and the origin of variations differ between the eastern and western parts of the monsoon-westerlies transition area. We have investigated the mechanisms producing moisture variability in the two parts of the transition area by performing a composite analysis of particularly wet and dry periods. The wet periods in the eastern part of the monsoon-westerlies transition area (particularly in north-eastern China) are related to an intensification of the pressure gradient between the western Pacific and Asia accompanied by an enhancement of the East Asian summer monsoon (Fig. 7d, e). This results in an increased summer monsoonal precipitation. According to the model, moisture variations in this part of the transition zone may be directly related to variability in the East Asian monsoonal system.

In contrast, the wet periods in the western part of the monsoonal boundary area (in western China) are characterized by a weak East Asian monsoon and a strengthened westerly wind circulation (Fig. 7b, c). Compared to the wet phases in the eastern part of the transition area, these periods are characterized by a cooler summer climate in the mid-latitudes and a warmer summer climate in the tropics, leading to a southward shift and strengthening of the subtropical westerly jet stream. The substantial changes that occur in the westerly wind system suggest that moisture variations in the western part of the transition zone are largely due to variability in the westerly winds, which probably also exert a strong influence on the processes operating during the winter and spring seasons.

\section{Conclusions}

(1) Pollen and geochemical analyses of sediments from Lake Khuisiin have yielded a detailed vegetation history for this area in the south-eastern Khangai Mountains of central Mongolia, documenting changes from dry steppe (ca AD 760-950), to Larix forest steppe (ca AD 950-1170), Larix-Betula forest steppe (ca AD 1170-1380), meadow (ca AD 1380-1830), and back to Larix-Betula forest steppe (ca AD 1830-2005).

(2) Although increased grazing over the last century may have reduced the proportion of Poaceae in the vegetation and triggered an increase in Artemisia, the general forest regeneration over the last millennium probably resulted from climate change rather than from human activity. We infer that, at least between AD 760 and 1950, climate has been the dominant driver of vegetation change within the study area. This does not exclude the possibility that the unique Mongolian forest steppe vegetation represents an ancient anthropogenic ecosystem that developed as a result of human-vegetation co-evolution, 
but it does suggest that any such natural-anthropogenic transition did not occur during the last millennium.

(3) Ordination of 27 moisture records reflecting centennial-scale changes in moisture levels reveals that many records indicate two distinct turnovers in moisture conditions at about AD 1500 and AD 1900, which is in agreement with our Mongolian record. The climatic conditions at most of these sites were wetter during the MWP and LIA than they are today, and for most sites the wettest period during the last 1200 years was the LIA. However, we found many inconsistencies with no clear spatial pattern within the moisture records. The records from monsoon-westerlies transition area mostly show a greater moisture variability than those from areas dominated by either the westerlies or the summer monsoon, which may indicate that they are more sensitive to large-scale climate change. This result is corroborated by the simulated effective moisture variability from the millennium run performed in the MPI Earth System Model. However, the origin of variability in the monsoon-westerlies transition area differs between east (monsoon-driven) and west (westerlies-driven). Our results indicate that strong spatial differences can be expected in future moisture changes during the course of climate warming, but that the relative amplitude of such changes maybe greatest in the monsoon-westerlies transition area.

\section{Acknowledgments}

The authors would like to thank Richard Telford (University of Bergen, Norway) for advice regarding data analysis, and Liv Heinecke (AWI-Potsdam and University of Potsdam, Germany) for assistance with the laboratory analyses. The authors also acknowledge Johann Jungclaus and the Millennium Consortium at the Max Planck Institute for Meteorology in Hamburg, Germany, for providing the climate model simulation, which was performed at the German Climate Computing Center (DKRZ) in Hamburg, Germany. The doctoral research by Fang Tian is funded by the "Helmholtz-China Scholarship Council (CSC) Young Scientist Fellowship” (No. 20100813030). This research has been supported by the German Research Foundation (Deutsche Forschungsgemeinschaft, DFG).

\section{Appendix A. Supplementary material}

Supplementary material related to this article can be found at http://dx.doi.org/10.1016/j.quascirev.2013.05.005.

\section{References}

An, C.B., Chen, F.H., Barton, L., 2008. Holocene environmental changes in Mongolia: a review. Global and Planetary Change 63, 283-289.

Angerer, J., Han, G.D., Fujisaki, I., Havstad, K., 2008. Climate change and ecosystems of Asia with emphasis on Inner Mongolia and Mongolia. Rangelands 30, 46-51.

Asner, G.P., Elmore, A.J., Olander, L.P., Martin, R.E., Harris, A.T., 2004. Grazing systems, ecosystem responses, and global change. Annual Review of Environment and Resources 29, 261-301.

Batima, P., Natsagdorj, L., Gombluudev, P., Erdenetsetseg, B., 2005. Observed Climate Change in Mongolia. Assessments of Impacts and Adaptations to Climate Change (AIACC). Working Paper 12.

Bauer, E., Claussen, M., Brovkin, V., Huenerbein, A., 2003. Assessing climate forcings of the Earth system for the past millennium. Geophysical Research Letters 30, 1276-1279.

Beer, R., Tinner, W., 2008. Four thousand years of vegetation and fire history in the spruce forests of northern Kyrgyzstan (Kungey Alatau, Central Asia). Vegetation History and Archaeobotany 17, 629-638.

Beug, H.J., 2004. Leitfaden der Pollenbestimmung für Mitteleuropa und angrenzende Gebiete. Verlag Dr. München: Friedrich Pfeil (in German).

Beuning, K.R.M., Talbot, M.R., Kelts, K., 1997. A revised 30,000-year paleoclimatic and paleohydrologic history of Lake Albert, East Africa. Palaeogeography, Palaeoclimatology, Palaeoecology 136, 259-279.
Bjune, A.E., Seppä, H., Birks, H.J.B., 2009. Quantitative summer-temperature reconstructions for the last 2000 years based on pollen-stratigraphical data from northern Fennoscandia. Journal of Paleolimnology 41, 43-56.

Blaauw, M., Christen, J.A., 2011. Flexible paleoclimate age-depth models using an autoregressive gamma process. Bayesian Analysis 6, 457-474.

Briffa, K.R., Bartholin, T.S., Eckstein, D., Jones, P.D., Karlén, W., Schweingruber, F.H., Zetterberg, P., 1990. A 1400-year tree-ring record of summer temperatures in Fennoscandia. Nature 346, 434-439.

Buttler, A., Warner, B.G., Grosvernier, P., Yvan, M., 1996. Vertical patterns of testate amoebae (Protozoa: Rhizopoda) and peat-forming vegetation on cutover bogs in the Jura, Switzerland. New Phytologist 134, 371-382.

Cao, X.Y., Tian, F., Xu, Q.H., Li, Y.C., Zhang, Z.Q., Jia, H.J., Zhang, L.Y., Wang, X.L., 2007. Pollen influx and comparison with surface pollen in the east part of Yinshan Mountains. Acta Palaeontologica Sinica 46, 411-419 (in Chinese, with English Abstr.).

Chen, J.A., Wan, G.J., Zhang, D.D., Zhang, F., Huang, R.G., 2004. Environmental records of lacustrine sediments in different time scales: sediment grain size as an example. Science in China Series D: Earth Sciences 47, 954-960.

Chen, F.H., Huang, X.Z., Zhang, J.W., Holmes, J.A., Chen, J.H., 2006. Humid Little Ice Age in arid central Asia documented by Bosten Lake, Xinjiang, China. Science in China Series D: Earth Sciences 49, 1280-1290.

Chen, F.H., Yu, Z.C., Yang, M.L., Ito, E., Wang, S.M., Madsen, D.B., Huang, X.Z., Zhao, Y., Sato, T., Birks, H.J.B., Boomer, I., Chen, J.H., An, C.B., Wünnemann, B., 2008. Holocene moisture evolution in arid central Asia and its out-of-phase relationship with Asian monsoon history. Quaternary Science Reviews 27, 351-364.

Chen, J.H., Chen, F.H., Zhang, E.L., Brooks, S.J., Zhou, A.F., Zhang, J.W., 2009. A 1000 year chironomid-based salinity reconstruction from varved sediments of Sugan Lake, Qaidam Basin, arid northwest China, and its palaeoclimatic significance. Chinese Science Bulletin 54, 3749-3759.

Chen, F.H., Chen, J.H., Homes, J., Boomer, I., Austin, P., Gates, J.B., Wang, N.L. Brooks, S.J., Zhang, J.W., 2010. Moisture changes over the last millennium in arid central Asia: a review, synthesis and comparison with monsoon region. Quaternary Science Reviews 29, 1055-1068.

Chen, H.F., Song, S.R., Lee, T.Q., Löwemark, L., Chi, Z.Q., Wang, Y., Hong, E., 2010. A multiproxy lake record from Inner Mongolia displays a late Holocene teleconnection between Central Asian and North Atlantic climates. Quaternary International 227, 170-182.

Chen, H., Yin, K.P., Wang, H.Y., Zhong, S.X., Wu, N., Shi, F.S., Zhu, D., Zhu, Q.A. Wang, W.F., Ma, Z.H., Fang, X.Q., Li, W.Z., Zhao, P.X., Peng, C.H., 2011. Detecting one-hundred-year environmental changes in western China using seven-year repeat photography. PLoS ONE 6, e25008.

Chen, Y.F., Zhao, Z.Z., 2009. Preliminary study on excess ${ }^{210} \mathrm{~Pb}$ flux characteristic of lake sediment in arid regions and its implication for aeolian activity. Journal of Lake Sciences 21, 813-818 (in Chinese, with English Abstr.).

Chu, G.Q., Sun, Q., Gu, Z.Y., Rioual, P., Liu, Q., Wang, K.J., Han, J.T., Liu, J.Q., 2009. Dust records from varved lacustrine sediments of two neighboring lakes in northeastern China over the last 1400 years. Quaternary International 194, 108-118.

Chuluun, T., Ojima, D. 2002. Land use change and carbon cycle in arid and semi-arid lands of East and Central Asia. Science in China Series C: Life Sciences 45, 48-54.

Conroy, J.L., Overpeck, J.T., Cole, J.E., Shanahan, T.M., Miriam, S.K., 2008. Holocene changes in eastern tropical Pacific climate inferred from a Galápagos lake sediment record. Quaternary Science Reviews 27, 1166-1180.

D’Arrigo, R., Jacoby, G., Pederson, N., Frank, D., Buckley, B., Nachin, B., Mijiddorj, R. Dugarjav, C., 2000. Mongolian tree-rings, temperature sensitivity and reconstructions of Northern Hemisphere temperature. The Holocene 10, 669-672.

D’Arrigo, R., Jacoby, G., Frank, D., Pederson, N., Cook, E., Bnuckley, B., Nachin, B., Mijiddorj, R., Dugarjav, C., 2001. 1738 years of Mongolian temperature variability inferred from a tree-ring width chronology of Siberian pine. Geophysical Research Letters 28, 543-546.

Dearing, J.A., 1997. Sedimentary indicators of lake-level changes in the humid temperate zone: a critical review. Journal of Paleolimnology 18, 1-14.

Dietze, E., Hartmann, K., Diekmann, B., IJmker, J., Lehmkuhl, F., Opitz, S., Stauch, G. Wünnemann, B., Borchers, A., 2012. An end-member algorithm for deciphering modern detrital processes from lake sediments of Lake Donggi Cona, NE Tibetan Plateau, China. Sedimentary Geology 243-244, 169-180.

Digerfeldt, G., Olsson, S., Sandgren, P., 2000. Reconstruction of lake-level changes in Lake Xinias, central Greece, during the last 40000 years. Palaeogeography, Palaeoclimatology, Palaeoecology 158, 65-82.

Ding, Y.H., 2007. The variability of the Asian summer monsoon. The Variability of the Asian Summer Monsoon 85, 21-54.

Dulamsuren, C., Hauck, M., Bader, M., Oyungerel, S., Osokhjargal, D., Nyambayar, S., Leuschner, C., 2009a. The different strategies of Pinus sylvestris and Larix sibirica to deal with summer drought in a northern Mongolian forest-steppe ecotone suggest a future superiority of pine in a warming climate. Canadian Journal of Forest Research 39, 2520-2528.

Dulamsuren, C., Hauck, M., Bader, M., Osokhjargal, D., Oyungerel, S., Nyambayar, S., Runge, M., Leuschner, C., 2009b. Water relations and photosynthetic performance in Larix sibirica growing in the forest-steppe ecotone of northern Mongolia. Tree Physiology 29, 99-110.

Dulamsuren, C., Hauck, M., Khishigjargal, M., Leuschner, H.H., Leuschner, C., 2010a. Diverging climate trends in Mongolian taiga forests influence growth and regeneration of Larix sibirica. Oecologia 163, 1091-1102.

Dulamsuren, C., Hauck, M., Leuschner, C., 2010b. Recent drought stress leads to growth reductions in Larix sibirica in the western Khentey, Mongolia. Global Change Biology 16, 3025-3035. 
Dulamsuren, C., Hauck, M., Leuschner, H.H., Leuschner, C., 2011. Climate response of tree-ring width in Larix sibirica growing in the drought-stressed foreststeppe ecotone of northern Mongolia. Annals of Forest Science 68, 275-282.

Esper, J., 2000. Paläoklimatische Untersuchungen an Jahrringen im Karakorum und Thien Shan Gebirge (Zentralasien). Bonner Geographische Abhandlungen 103, 126 (in German)

Faegri, K., Iversen, J., 1989. Testbook of Pollen Analysis, fourth ed. John Wiley \& Sons, London.

Feng, Z.D., Wang, W.G., Guo, L.L., Khosbayar, P., Narantsetseg, T., Jull, A.J.T., An, C.B., Li, X.Q., Zhang, H.C., Ma, Y.Z., 2005. Lacustrine and eolian records of Holocene climate changes in the Mongolian Plateau: preliminary results. Quaternary International 136, 25-32.

Finney, B.P., Johnson, T.C., 1991. Sedimentation in Lake Malawi (East Africa) during the past 10,000 years: a continuous paleoclimatic record from the southern tropics. Palaeogeography, Palaeoclimatology, Palaeoecology 85, 351-366.

Fowell, S.J., Hansen, B.C.S., Peck, J.A., Khosbayar, P., Ganbold, E., 2003. Mid to late Holocene climate evolution of the Lake Telmen Basin, North Central Mongolia based on palynological data. Quaternary Research 59, 353-363.

Gao, J.H., Liu, J., Wang, S.M., 2006. Overview on studies of Medieval warm period in China. Scientia Geographica Sinica 26, 376-383.

Gong, D.Y., Wang, S.W., Zhu, J.H., 2001. East Asian winter monsoon and Arctic Oscillation. Geophysical Research Letters 28, 2073-2076.

Granados, I., Toro, M., 2000. Recent warming in a high mountain lake (Laguna Cimera, Central Spain) inferred by means of fossil chironomids. Journal of Limnology 59, 109-119.

Grimm, E.C., 1987. CONISS: a FORTRAN 77 program for stratigraphically constrained cluster analysis by the method of incremental sum of squares. Computers and Geosciences 13, 13-35.

Grimm, E.C., 1991. TILIA and TILIAGRAPH Software. Illinois State Museum, Springfield.

Grunert, J., Lehmkuhl, F., Walther, M., 2000. Paleoclimatic evolution of the Uvs Nuur basin and adjacent areas (Western Mongolia). Quaternary International 65-66, 171-192.

Gunin, P.D., Vostokova, E.A., 1995. Ecosystems of Mongolia (map), Joint Russianmongolian Complex Biological Expedition with Assistance from UNEP. Moscow.

Gunin, P.D., Vostokova, E.A., Dorofeyuk, N.I., Tarasov, P.E., Black, C.C., 1999. Vegetation Dynamics of Mongolia. Kluwer Academic Publishers, London.

Hassan, K.M., Swinehart, J.B., Spalding, R.F., 1997. Evidence for Holocene environmental change from $\mathrm{C} / \mathrm{N}$ ratios, and $\delta^{13} \mathrm{C}$ and $\delta^{15} \mathrm{~N}$ values in Swan Lake sediments, western Sand Hills Nebraska. Journal of Paleolimnology 18, 121-130.

He, B.Y., Zhang, S., Cai, S.M., 2003. Climatic changes recorded in peat from the Dajiu Lake basin in Shennongjia since the last 2600 years. Marine Geology \& Quaternary Geology 23, 109-115 (in Chinese, with English Abstr.).

Herzschuh, U., 2006. Palaeo-moisture evolution in monsoonal central Asia during the last 50,000 years. Quaternary Science Reviews 25, 163-178.

Herzschuh, U., 2007. Reliability of pollen ratios for environmental reconstructions on the Tibetan Plateau. Journal of Biogeography 34, 1265-1273.

Herzschuh, U., Tarasov, P., Wünnemann, B., Hartmann, K., 2004. Holocene vegetation and climate of the Alashan Plateau, NW China, reconstructed from pollen data. Palaeogeography, Palaeoclimatology, Palaeoecology 211, 1-17.

Hilbig, W., 1995. The Vegetation of Mongolia. SPB Academic Publishing, Amsterdam, The Netherlands.

Hu, C.Y., Henderson, G.M., Huang, J.H., Xie, S.C., Sun, Y., Johnson, K.R., 2008 Quantification of Holocene Asian monsoon rainfall from spatially separated cave records. Earth and Planetary Science Letters 266, 221-232.

Hughen, K.A., Jonathan, T., Overpeck, J.T., Anderson, R.F., 2000. Recent warming in a 500-year palaeotemperature record from varved sediments, Upper Soper Lake, Baffin Island, Canada. The Holocene 10, 9-19.

Hurrell, J.W., Kushnir, Y., Ottersen, G., Visbeck, M. (Eds.), 2003. The North Atlantic Oscillation: Climatic Significance and Environmental Impact. Geophysical Monograph Series, vol. 134. AGU, Washington, D.C., p. 279. http://dx.doi.org/ $10.1029 / G M 134$.

IPCC (Intergovernmental Panel on Climate Change), 2007. Climate change 2007: synthesis report. In: Core Writing Team, Pachauri, R.K., Reisinger, A. (Eds.), Contribution of Work Group of I, II and III to the Fourth Assessment Report of Intergovernmental Panel on Climate Change. IPCC, Goneva, Switcherland.

Jacoby, G.C., D’Arrigo, R., Davaajamts, T., 1996. Mongolian tree rings and 20thCentury warming. Science 273, 771-773.

Jiang, J.M., Wu, J.L., Shen, J., 2004. Lake sediment records of climatic and environmental change in Angulinao Lake. Scientia Geographica Sinica 24, 346-351 (in Chinese, with English Abstr.)

Jin, Z.D., Wang, S.M., Shen, J., Zhang, E.L., Li, F.C., Ji, J.F., Lu, X.W., 2001. Chemica weathering since the Little Ice Age recorded in lake sediments: a high-resolution proxy of past climate. Earth Surface Processes and Landforms 26, 775782.

Jungclaus, J.H., 2008. MPI-M Earth System Modelling Framework: Millennium Full Forcing Experiment (Ensemble Member 1). World Data Center for Climate. CERA-DB "mil0010". http://cera-www.dkrz.de/WDCC/ui/Compact.jsp? acronym $=$ mil0010.

Jungclaus, J.H., Lorenz, S.J., Timmreck, C., Reick, C.H., Brovkin, V., Six, K., Segschneider, J., Giorgetta, M.A., Crowley, T.J., Pongratz, J., Krivova, N.A., Vieira, L.E., Solanki, S.K., Klocke, D., Botzet, M., Esch, M., Gayler, V., Haak, H. Raddatz, T.J., Roeckner, E., Schnur, R., Widmann, H., Claussen, M., Stevens, B. Marotzke, J., 2010. Climate and carbon-cycle variability over the last millennium. Climate of the Past 6, 723-737.
Krasnoshchekov, Y.N., 2010. Soils and the soil cover of mountainous tundra and forest landscapes in the central Khangai of Mongolia. Eurasian Soil Science 43. $117-126$.

Krivonogov, S.K., Takahara, H., Yamamuro, M., Preis, Y.I., Khazina, I.V., Khazin, L.B., Kuzmin, Y.V., Safonova, I.Y., Ignatova, N.V., 2012. Regional to local environmental changes in southern Western Siberia: evidence from biotic records of mid to late Holocene sediments of Lake Beloye. Palaeogeography, Palaeoclimatology, Palaeoecology 331-332, 177-193.

Ku, T.L., Li, H.C., 1998. Speleothems as high-resolution paleoenvironment archives: records from northeastern China. In: Proceedings of the Indian Academy of Sciences. Earth and Planetary Sciences, vol. 107, pp. 321-330.

Lehmkuhl, F., Klinge, M., Stauch, G., 2004. The extent of Late Pleistocene glaciations in the Altai and Khangai Mountains. Quaternary Sciences 2C, 243-254.

Leonelli, G., Pelfini, M., di Cella, U.M., Garavaglia, V., 2011. Climate warming and the recent treeline shift in the European Alps: the role of geomorphological factors in High-Altitude Sites. Ambio 40, 264-273.

Li, S.J., Wang, X.T., Xia, W.L., Li, W.C., 2004. The little ice age climate fluctuations derived from lake sediments of Goulucuo, Qinghai-Xizang Plateau. Quaternary Sciences 24, 578-584 (in Chinese, with English Abstr.).

Li, W.Y., Yao, Z.J., 1990. A study on the quantitative relationship between Pinus pollen in surface sample and Pinus vegetation. Journal of Integrative Plant Biology 32, 943-950 (in Chinese, with English Abstr.).

Li, W.Y., 1993. Some problems of Holocene pollen analysis. In: Zhang, L.S. (Ed.) Research of the Historical Change of the Environment for Human Survival in China. Ocean Press, Beijing, pp. 4-10 (in Chinese).

Li, W.Y., Yao, Z.J., 1993. Research of the Quaternary Vegetation and Environment in the Northern and Middle Subtropical Zone in China. Ocean Press, Beijing (in Chinese).

Li, Y.C., Xu, Q.H., Yang, X.L., Zheng, Z.H., 2005. Pollen assemblages of major steppe communities in China. Acta Ecologica Sinica 25, 555-564 (in Chinese, with English Abstr.).

Li, Y.C., Bunting, M.J., Xu, Q.H., Jiang, S.X., Ding, W., Hun, L.Y., 2011. Pollen-vegetation-climate relationships in some desert and desert-steppe communities in northern China. The Holocene 21, 997-1010.

Liu, H.Y., Cui, H.T., Pott, R., Speier, M., 1999. The surface pollen of the woodlandsteppe ecotone in southeastern Inner Mongolia, China. Review of Palaeobotany and Palynology 105, 237-250.

Liu, J., Chen, X., Wang, S.M., Zheng, Y.Q., 2004. Palaeoclimate simulation of Little Ice Age. Progress in Natural Science 14, 716-724.

Liu, J.B., Chen, F.H., Chen, J.H., Xia, D.S., Xu, Q.H., Wang, Z.L., Li, Y.C., 2011. Humid Medieval Warm Period recorded by magnetic characteristics of sediments from Gonghai Lake, Shanxi, North China. Chinese Science Bulletin 56, 2464-2474.

Liu, W.G., Liu, Z.H., An, Z.S., Wang, X.L., Chang, H., 2010. Wet climate during the 'Little Ice Age' in the arid Tarim Basin, northwestern China. The Holocene 21, 409-416.

Liu, X.Q., Herzschuh, U., Shen, J., Jiang, Q.F., Xiao, X.Y., 2008. Holocene environmental and climatic changes inferred from Wulungu Lake in northern Xinjiang, China. Quaternary Research 70, 412-425.

Liu, Y., An, Z.S., Linderholm, H.W., Chen, D.L., Song, H.M., Cai, Q.F., Sun, J.Y., Tian, H., 2009. Annual temperatures during the last 2485 years in the mid-eastern Tibetan Plateau inferred from tree rings. Science in China Series D: Earth Sciences 52, 348-359.

Ma, J.Z., Li, D., Zhang, J.W., Edmunds, W.M., Prudhomme, C., 2003. Groundwater recharge and climatic change during the last 1000 years from unsaturated zone of SE Badain Jaran Desert. Chinese Science Bulletin 48, 1469-1474.

Ma, Y.Z., Liu, K.B., Feng, Z.D., Sang, Y.L., Wang, W., Sun, A.Z., 2008. A survey of modern pollen and vegetation along a south-north transect in Mongolia. Journal of Biogeography 35, 1512-1532.

Ma, Z.G., Fu, C.B., 2006. Some evidence of drying trend over northern China from 1951 to 2004 . Chinese Science Bulletin 51, 2913-2925.

Mackay, A.W., Ryves, D.B., Battarbee, R.W., Flower, R.J., Jewson, D., Rioual, P., Sturm, M., 2005. 1000 years of climate variability in central Asia: assessing the evidence using Lake Baikal (Russia) diatom assemblages and the application of a diatom-inferred model of snow cover on the lake. Global and Planetary Change 46, 281-297.

Mahapatra, D.M., Chanakya, H.N., Ramachandra, T.V., 2011. C: N ratio of sediments in a sewage fed Urban Lake. International Journal for Geology 5, 86-92.

Maher, L.J., 1981. Statistics for microfossil concentration measurements employing samples spiked with marker grains. Review of Palaeobotany and Palynology 32, 153-191.

Man, Z.M., 2009. The Climate Research During the History Period in China. Shandong Education Press, Jinan, pp. 316-329 (in Chinese)

Mayewski, P.A., Rohling, E.E., Stager, J.C., Karlén, W., Maasch, K.A., Meeker, L.D. Meyerson, E.A., Gasse, F., van Kreveld, S., Holmgren, K., Lee-Thorp, J., Rosqvist, G., Racki, F., Staubwasser, M., Schneider, R.R., Steig, E.J., 2004. Holocene climate variability. Quaternary Research 62, 243-255.

Meyers, P.A., 1994. Preservation of elemental and isotopic source identification of sedimentary organic-matter. Chemical Geology 114, 289-302.

Meyers, P.A., Ishiwatari, R., 1993. Lacustrine organic geochemistry-an overview of indicators of organic-matter sources and diagenesis in lake-sediments. Organic Geochemistry 20, 867-900.

Meyers, P.A., Lallier-Vergès, E., 1999. Lacustrine sedimentary organic matter records of Late Quaternary paleoclimates. Journal of Paleolimnology 21, 345-372.

Moore, P.D., Webb, J.A., Collinson, M.E., 1991. Pollen Analysis, second ed. Blackwell Science, Oxford. 
Murakami, T., Katsuta, N., Yamamoto, K., Takamatsu, N., Takano, M., Oda, T., Matsumoto, G.I., Horiuchi, K., Kawai, T., 2010. A 27-kyr record of environmental change in central Asia inferred from the sediment record of Lake Hovsgol, northwest Mongolia. Journal of Paleolimnology 43, 369-383.

Na, R., 2008. The Development Study of Mongolia Grassland Animal Husbandry. Master thesis. Inner Mongolia University, Hohhot, China (in Chinese, with English Abstr.).

Natsagdorj, L., 2000. Climate change. In: Batime, P., Dagvadorj, D. (Eds.), Climate Change and its Impacts in Mongolia. JEMR Publishing, Ulaanbaatar

Paillard, D., Labeyrie, L., Yiou, P., 1996. Macintosh program performs time-series analysis. EOS Transactions American Geophysical Union 77, 379.

Paulsen, D.E., Li, H.C., Ku, T.L., 2003. Climate variability in central China over the last 1270 years revealed by high-resolution stalagmite records. Quaternary Science Reviews 22, 691-701.

Pederson, N., Jacoby, G.C., D’Arrigo, R., Cook, E.R., Buckley, B.M., Dugarjav, C., Mijiddorj, R., 2001. Hydrometeorological reconstructions for northeastern Mongolia derived from tree Rings: AD 1651-1995. Journal of Climate 14, $872-881$.

Peixoto, J.P., Oort, A.H., 1992. Physics of Climate. American Institute of Physics, New York, p. 520.

Poska, A., Meltsov, V., Sugita, S., Vassiljev, J., 2011. Relative pollen productivity estimates of major anemophilous taxa and relevant source area of pollen in a cultural landscape of the hemi-boreal forest zone (Estonia). Review of Palaeobotany and Palynology 167, 30-39.

Prokopenko, A.A., Khursevich, G.K., Bezrukova, X.B., Kuzmin, M.I., Boes, X., Williams, D.F., Fedenya, S.A., Kulagina, N.V., Letunova, P.P., Abzaeva, A.A., 2007. Paleoenvironmental proxy records from Lake Hovsgol, Mongolia, and a synthesis of Holocene climate change in the Lake Baikal watershed. Quaternary Research 68, 2-17.

R Development Core Team, 2012. R: a Language and Environment for Statistical Computing. R Foundation for Statistical Computing, Vienna.

Räsänen, S., Suutari, H., Nielsen, A.B., 2007. A step further towards quantitative reconstruction of past vegetation in Fennoscandian boreal forests: pollen productivity estimates for six dominant taxa. Review of Palaeobotany and Palynology 146, 208-220.

Rösch, M., Fischer, E., Märkle, T., 2005. Human diet and land use in the time of the Khans-archaeobotanical research in the capital of the Mongolian Empire, Qara Qorum, Mongolia. Vegetation History and Archaeobotany 14, 485-492.

Rudaya, N., Tarasov, P., Dorofeyuk, N., Solovieva, N., Kalugin, I., Andreev, A., Darvin, A., Diekmann, B., Riedel, F., Tserendash, N., Wagner, M., 2009. Holocene environments and climate in the Mongolian Altai reconstructed from the Hoton-Nur pollen and diatom records: a step towards better understanding climate dynamics in Central Asia. Quaternary Science Reviews 28, $540-554$.

Ryves, D.B., Mills, K., Bennike, O., Brodersen, K.P., Lamb, A.L., Leng, M.J., Russell, J.M., Ssemmand, I., 2011. Environmental change over the last millennium recorded in two contrasting crater lakes in western Uganda, eastern Africa (Lakes Kasenda and Wandakara). Quaternary Science Reviews 30, 555-569.

Saandar, M., Sugita, M., 2004. Digital Atlas of Mongolian Natural Environments, (1) Vegetation, Soil, Ecosystem and Water, CD-ROM. Monmap Engineering Service Co., Ltd, Ulaanbaatar 210646, Mongolia.

Sankey, T.T., Montagne, C., Graumlich, L., Lawrence, R., Nielsen, J., 2006. Lower forest-grassland ecotones and 20th Century livestock herbivory effects in northern Mongolia. Forest Ecology and Management 233, 36-44.

Sankey, T.T., Sankey, J.B., Weber, K.T., Montagne, C., 2009. Geospatial assessment of grazing regime shifts and sociopolitical changes in a Mongolian rangeland. Rangeland Ecology and Management 62, 522-530.

Sato, T., Kimura, F., Kitoh, A., 2007. Projection of global warming onto regional precipitation over Mongolia using a regional climate model. Journal of Hydrology 333, 144-154.

Schlütz, F., Dulamsuren, C., Wieckowska, M., Mühlenberg, M., Hauck, M., 2008. Late Holocene vegetation history suggests natural origin of steppes in the northern Mongolian mountain taiga. Palaeogeography, Palaeoclimatology, Palaeoecology 261, 203-217.

Sharkhuu, N., 2003. Recent change in the permafrost of Mongolia. In: Phillips, M., Springman, S.M., Arenson, L.U. (Eds.), Permafrost. Swets \& Zeitlinger, Lisse, pp. 1029-1034.

Shinneman, A.L.C., Almendinger, J.E., Umbanhowar, C.E., Edlund, M.B., Nergui, S., 2009. Paleolimnologic evidence for recent eutrophication in the valley of the Great Lakes (Mongolia). Ecosystems 12, 944-960.

Sjögren, P., van der Knaap, W.O., Huusko, A., van Leeuwen, J.F.N., 2008. Pollen productivity, dispersal, and correction factors for major tree taxa in the Swiss Alps based on pollen-trap results. Review of Palaeobotany and Palynology 152, $200-210$.

Sugita, S., 1993. A model of pollen source area for an entire lake. Quaterary Research 39, 239-244.

Sugita, S., Gaillard, M.J., Broström, A., 1999. Landscape openness and pollen records: a simulation approach. The Holocene 9, 409-421.

Talbot, M.R., Livingstone, D.A., 1989. Hydrogen index and carbon isotopes of lacustrine organic matter as lake level indicators. Palaeogeography, Palaeoclimatology, Palaeoecology 70, 121-137.

Tan, L.C., Cai, Y.J., An, Z.S., Edwards, R.L., Cheng, H., Shen, C.C., Zhang, H.W., 2010. Centennial-to decadal-scale monsoon precipitation variability in the semihumid region, northern China during the last 1860 years: records from stalagmites in Huangye Cave. The Holocene 21, 287-296.
Tan, L.C., Cai, Y.J., An, Z.S., Yi, L., Zhang, H.W., Qin, S., 2011. Climate patterns in north central China during the last $1800 \mathrm{yr}$ and their possible driving force. Climate of the Past 7, 685-692.

Tarasov, P., Dorofeyuk, N., Metel'tseva, E., 2000. Holocene vegetation and climate changes in Hoton-Nur basin, northwest Mongolia. Boreas 29, 117-126.

Tarasov, P., Granoszewski, W., Bezrukova, E., Brewer, S., Nita, M., Abzaeva, A. Oberhänsli, H., 2005. Quantitative reconstruction of the last interglacial vegetation and climate based on the pollen record from Lake Baikal, Russia. Climate Dynamics 25, 625-637.

ter Braak, C.J.F., 1988. CANOCO-a FORTRAN Program for Canonical Community Ordination by (Partial) (Detrended) (Canonical) Correspondence Analysis, Principal Components Analysis and Redundancy Analysis (Version 2.1). GLW, Wageningen, p. 95. Technical Rep. LWA-88-02.

ter Braak, C.J.F., Smilauer, P., 2002. CANOCO 4.5. Biometrics. Wageningen University and Research Center, Wageningen, p. 500.

Thompson, L.G., Mosley-Thompson, E., Davis, M.E., Lin, P.N., Henderson, K., Mashiotta, T.A., 2003. Tropical glacier and ice core evidence of climate change on annual to millennial time scales. Climatic Change 59, 137-155.

Tudhope, A.W., Chilcott, C.P., McCulloch, M.T., Cook, E.R., Chappell, J., Ellam, R.M., Lea, D.W., Lough, J.M., Shimmield, G.B., 2001. Variability in the El Niño-Southern oscillation through a glacial-interglacial cycle. Science 291, 1511-1517.

Vallentine, J.F., 2001. Grazing Management. Academic Press, London.

van Geel, B., Bokovenko, N.A., Burova, N.D., Chugunov, K.V., Dergachev, V.A. Dirksen, V.G., Kulkova, M., Nagler, A., Parzinger, H., van der Plicht, J., Vasiliev, S., Zaitseva, G.I., 2004. Climate change and the expansion of the Scythian culture after 850 BC: a hypothesis. Journal of Archaeological Science 31, 1735-1742.

Wang, B., Wu, R.G., Fu, X.H., 2000. Pacific-East Asian teleconnection: how does ENSO affect east Asian climate? Journal of Climate 13, 1517-1536.

Wang, F.X., Qian, N.F., Zhang, Y.L., Yang, H.Q., 1997. Pollen Flora of China, second ed. Science Press, Beijing.

Wang, H.Y., Liu, H.Y., Cui, H.T., Abrahamsen, N., 2001. Terminal Pleistocene/Holocene palaeoenvironmental changes revealed by mineral-magnetism measurements of lake sediments for Dali Nor area, southeastern Inner Mongolia Plateau, China. Palaeogeography, Palaeoclimatology, Palaeoecology 170, 115-132.

Wang, J.B., Zhu, L.P., 2008. Distribution features of elements in core sediments and their relationship with grain size in Lake Chen Co, southern Tibet. Journal of Lake Sciences 20, 715-722 (in Chinese, with English Abstr.).

Wang, L.C., Wu, J.T., Lee, T.Q., Lee, P.F., Leea, P.F., Chen, S.H., 2011. Climate changes inferred from integrated multi-site pollen data in northern Taiwan. Journal of Asian Earth Sciences 40, 1164-1170.

Wang, S.M., Liu, J., Zhou, J., 2003. The climate of Little Ice Age maximum in China. Journal of Lake Sciences 15, 369-376 (in Chinese, with English Abstr.).

Wang, S.W., Cai, J.N., Zhu, J.H., Gong, D.Y., 2002. Studies on climate change in China. Climate and Environmental Research 7,137-145 (in Chinese, with English Abstr.)

Wang, W.G., Feng, Z.D., Lee, X.Q., Zhang, H.C., Ma, Y.Z., An, C.B., Guo, L.L., 2004. Holocene abrupt climate shifts recorded in Gun Nuur lake core, northern Mongolia. Chinese Science Bulletin 49, 520-526.

Wang, Y.J., Cheng, H., Edwards, R.L., He, Y.Q., Kong, X.G., An, Z.S., Wu, J.Y., Kelly, M.J., Dykoski, C.A., Li, X.D., 2005. The Holocene Asian monsoon: links to solar changes and North Atlantic climate. Science 308, 854-857.

Wang, Y.B., Liu, X.Q., Yang, X.D., Zhang, E.L., Matsumoto, R., 2008. A 4000-year moisture evolution recorded by sediments of Lake Kusai in the Hoh Xil area, northern Tibetan Plateau. Journal of Lake Sciences 20, 605-612 (in Chinese, with English Abstr.).

Wang, W., Ma, Y.Z., Feng, Z.D., Meng, H.W., Sang, Y.L., Zhai, X.W., 2009. Vegetation and climate changes during the last $8660 \mathrm{cal}$. a BP in central Mongolia, based on a high-resolution pollen record from Lake Ugii Nuur. Chinese Science Bulletin 54, 1579-1589.

Wang, X.M., Chen, F.H., Zhang, J.W., Yang, Y., Li, J.J., Hasi, E., Zhang, C.X., Xia, D.S., 2010. Climate, desertification, and the rise and collapse of China's historical dynasties. Human Ecology 38, 157-172.

Wang, Y.B., Liu, X.Q., Herzschuh, U., 2010. Asynchronous evolution of the Indian and East Asian summer monsoon indicated by Holocene moisture patterns in monsoonal central Asia. Earth Science Reviews 103, 135-153.

Wang, Y.B., Herzschuh, U., 2011. Reassessment of Holocene vegetation change on the upper Tibetan Plateau using the pollen-based REVEALS model. Review of Palaeobotany and Palynology 168, 31-40.

Webster, P.J., Magan̆a, V.O., Palmer, T.N., Shukla, J., Tomas, R.A., Yanai, M., Yasunari, T., 1998. Monsoons: processes, predictability, and the prospects for prediction. Journal of Geophysical Research: Oceans 103, 14451-14510.

Weltje, G.J., 1997. End-member modeling of compositional data: numerical-statistical algorithms for solving the explicit mixing problem. Journal of Mathematical Geology 29, 503-549.

Weltje, G.J., Prins, M.A., 2003. Muddled or mixed? Inferring palaeoclimate from size distributions of deep-sea clastics. Sedimentary Geology 162, 39-62.

Weltje, G.J., Prins, M.A., 2007. Genetically meaningful decomposition of grain-size distributions. Sedimentary Geology 202, 409-424.

Wischnewski, J., Kramer, A., Kong, Z.C., Mackay, A.W., Simpson, G.L., Mischke, S. Herzschuh, U., 2011a. Terrestrial and aquatic responses to climate change and human impact on the southeastern Tibetan Plateau during the past two centuries. Global Change Biology 17, 3376-3391.

Wischnewski, J., Mackay, A.W., Appleby, P.G., Mischke, S., Herzschuh, U., 2011b. Modest diatom responses to regional warming on the southeast Tibetan Plateau during the last two centuries. Journal of Paleolimnology 46, 215-227. 
Xu, Q.H., Li, Y.C., Yang, X.L., Zheng, Z.H., 2007. Quantitative relationship between pollen and vegetation in northern China. Science in China Series D: Earth Sciences 50, 582-599.

Xu, Q.H., Xiao, J.L., Li, Y.C., Tian, F., Nakagawa, T., 2010. Pollen-based quantitative reconstruction of Holocene climate changes in the Daihai Lake area, Inner Mongolia, China. Journal of Climate 23, 2856-2868.

Yang, B., Wang, J., Bräuning, A., Dong, Z., Esper, J., 2009. Late Holocene climatic and environmental changes in arid central Asia. Quaternary International 194, $68-78$.

Yang, X.D., 1996. Pollen assemblage and palaeoclimate during last 2000 year in Ximencuo region, Qinghai. Acta Micropalaeontologica Sinca 13, 437-440 (in Chinese, with English Abstr.)

Yang, X.L., 2007. High Resolution Stalagmite $\delta^{18}$ O Records over the Past 1200 Years in the Eastern Qinghai-tibetan Plateau. PhD thesis. Lanzhou University, Lanzhou, China.

Yang, X.P., Zhu, Z.D., Jaekel, D., Owen, L., Han, J.M., 2002. Late Quaternary palaeoenvironment change and landscape evolution along the Keriya River, Xinjiang, China: the relationship between high mountain glaciation and landscape evolution in foreland desert regions. Quaternary International 97/98, 155-166.

Yang, X.P., Liu, Z., Zhang, F., White, P., Wang, X., 2006. Hydrological changes and land degradation in the southern and eastern Tarim Basin, Xinjiang, China. Land Degradation and Development 17, 381-392.

Yang, X.P., Scuderi, L., 2010. Hydrological and climatic changes in deserts of China since the Late Pleistocene. Quaternary Research 73, 1-9.

Yang, X.P., Scuderi, L., Paillou, P., Liu, Z.T., Li, H.W., Ren, X.Z., 2011. Quaternary environmental changes in the drylands of China - a critical review. Quaternary Science Reviews 30, 3219-3233.

Yarmolyuk, V.V., Kudryashova, E.A., Kozlovsky, A.M., Lebedev, V.A., Savatenkov, V.M. 2007. Late Cenozoic volcanism at the northeastern flank of the south Khanga Volcanic Region (central Mongolia): geochronology and formation conditions. Doklady Earth Sciences 417, 1320-1324.

Yin, Y., Liu, H.Y., He, S.Y., Zhao, F.J., Zhu, J.L., Wang, H.Y., Liu, G., Wu, X.C., 2011 Patterns of local and regional grain size distribution and their application to Holocene climate reconstruction in semi-arid Inner Mongolia, China. Palaeogeography, Palaeoclimatology, Palaeoecology 307, 168-176.

Yuan, Y.J., Han, S.T., 1991. Features of dry and wet changes for 500 years in the northern of Xinjiang. Journal of Glaciology and Geocryology 13, 315-322 (in Chinese, with English Abstr.)

Zaitseva, G., van Geel, B., Bokovenko, N., Chugunov, K., Dergachev, V., Dirksen, V. Koulkova, M., Nagler, A., Parzinger, G., van der Plicht, J., Bourova, N. Lebedeva, L., 2004. Chronology and possible links between climatic and cultura change during the first millennium BC in southern Siberia and Central Asia. Radiocarbon 46, 259-276.
Zemmrich, A., Manthey, M., Zerbe, S., Oyunchimeg, D., 2010. Driving environmental factors and the role of grazing in grassland communities: a comparative study along an altitudinal gradient in Western Mongolia. Journal of Arid Environments $74,1271-1280$.

Zhai, Q.M., Guo, Z.Y., Li, Y.L., Li, R.Q., 2006. Annually laminated lake sediments and environmental changes in Bashang Plateau, North China. Palaeogeography, Palaeoclimatology, Palaeoecology 241, 95-102.

Zhang, C.J., Zhang, W.Y., Feng, Z.D., Mischke, S., Gao, X., Gao, D., Sun, F.F., 2012. Holocene hydrological and climatic change on the northern Mongolian Plateau based on multi-proxy records from Lake Gun Nuur. Palaeogeography, Palaeoclimatology, Palaeoecology 323-325, 75-86.

Zhang, D.E., 2004. Variation of dry-wet climate and severe drought events as revealed in the climate records of China over the past 1000 years. Science \& Technology Review 8, 47-49 (in Chinese, with English Abstr.).

Zhang, J.W., Jin, M., Chen, F.H., Battarbee, R.W., Henderson, A.C.G., 2003. Highresolution precipitation variations in the Northeast Tibetan Plateau over the last 800 years documented by sediment cores of Qinghai Lake. Chinese Science Bulletin 48, 1451-1456.

Zhang, K., Zhao, Y., Yu, Z.C., Zhou, A.F., 2010. A 2700-year high resolution pollen record of climate change from varved Sugan Lake in the Qaidam Basin, northeastern Tibetan Plateau. Palaeogeography, Palaeoclimatology, Palaeoecology 297, 290-298.

Zhang, P.Z., Cheng, H., Edwards, R.L., Chen, F.H., Wang, Y.J., Yang, X.L., Liu, J., Tan, M. Wang, X.F., Liu, J.H., An, C.L., Dai, Z.B., Zhou, J., Zhang, D.Z., Jia, J.H., Jin, L.Y., Johnson, K.R., 2008. A test of climate, sun, and culture relationships from an 1810-Year Chinese cave record. Science 322, 940-942.

Zhang, X.L., He, X.Y., Li, J.B., Davi, N., Chen, Z.J., Cui, M.X., Chen, W., Li, N., 2011. Temperature reconstruction (1750-2008) from Dahurian larch tree-rings in an area subject to permafrost in Inner Mongolia, Northeast China. Climate Research 47, 151-159.

Zhao, C., Yu, Z.C., Zhao, Y., Ito, E., 2009. Possible orographic and solar controls of Late Holocene centennial-scale moisture oscillations in the northeastern Tibetan Plateau. Geophysical Research Letters 36, L21705. http://dx.doi.org/10.1029/ 2009 GL040951.

Zhao, Y., Yu, Z.C., Li, X.J., Zhao, C., Chen, F.H., Zhang, K., 2010. Late Holocene vegetation and climate oscillations in the Qaidam Basin of the northeastern Tibetan Plateau. Quaternary Research 73, 59-69.

Zhong, W., 1997. The lacustrine sediment records of the environmental changes since the Little Ice Age (LIA) in the northern parts of East Xinjiang. Journal of Xinjiang University 14, 78-84 (in Chinese, with English Abstr.).

Zhong, W., Wang, L.G., Li, S., 2004. Preliminary study of climate characteristics during 9th-14th century in extremely drought southern Xinjiang. Journal of Arid Land Resources and Environment 18, 22-27 (in Chinese, with English Abstr.). 